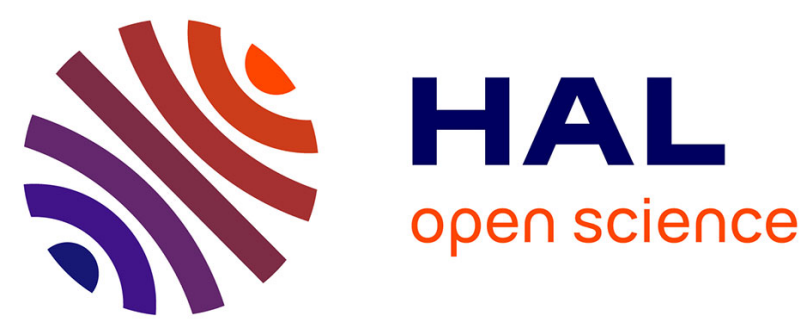

\title{
When is flow re-entrainment important for the flushing time in coastal reef systems?
}

\author{
Gundula Winter, B Castelle, R J Lowe, J E Hansen, R Mccall
}

\section{To cite this version:}

Gundula Winter, B Castelle, R J Lowe, J E Hansen, R Mccall. When is flow re-entrainment important for the flushing time in coastal reef systems?. Continental Shelf Research, 2020. hal-03044542

\section{HAL Id: hal-03044542 \\ https://hal.science/hal-03044542}

Submitted on 7 Dec 2020

HAL is a multi-disciplinary open access archive for the deposit and dissemination of scientific research documents, whether they are published or not. The documents may come from teaching and research institutions in France or abroad, or from public or private research centers.
L'archive ouverte pluridisciplinaire HAL, est destinée au dépôt et à la diffusion de documents scientifiques de niveau recherche, publiés ou non, émanant des établissements d'enseignement et de recherche français ou étrangers, des laboratoires publics ou privés. 
1 When is flow re-entrainment important for the flushing time in coastal reef systems?

3 G. Winter ${ }^{1}$, B. Castelle ${ }^{2}$, R.J. Lowe ${ }^{3,4}$, J.E. Hansen ${ }^{3,5}$, R. McCall ${ }^{1}$

$4 \quad{ }^{1}$ Deltares, Dept. ZKS, P.O. Box 177, 2600 MH Delft, The Netherlands.

$5 \quad{ }^{2}$ CNRS, UMR EPOC, University Bordeaux, Pessac, France.

$6{ }^{3}$ Oceans Graduate School and the UWA Oceans Institute, University of Western Australia,

7 Crawley, Australia.

$8{ }^{4}$ ARC Centre of Excellence for Coral Reef Studies, University of Western Australia,

9 Crawley, Australia.

$10{ }^{5}$ School of Earth Sciences, University of Western Australia, Crawley, Australia.

12 Corresponding author: Gundula Winter (gundulawinter@gmail.com) 


\section{Abstract}

16 The rates of water exchange between coastal reef systems and the surrounding ocean are key

17 physical drivers of water quality and reef ecosystems. It is generally assumed that water

18 exiting a reef system through reef channels is predominantly replaced by 'new' water from

19 offshore. However, exiting water may also recirculate back into the reef system reducing the

20 rate of exchange between the reef and the ocean, which has implications for reef water

21 temperatures, nutrient fluxes and population connectivity. To quantify flow re-entrainment at

22 a rocky reef site in southwestern Australia, flow patterns were measured with GPS-tracked

23 drifters during a two-week field experiment. The field observations were extended via a set of

24 idealized numerical experiments to determine the effect of variable oceanic forcing and reef

25 geometry on flow re-entrainment. The observations demonstrate that re-entrainment can vary

26 significantly and the numerical results support the hypothesis that re-entrainment increases

27 with increasing offshore wave height, increasing alongshore currents outside of the reef, and

28 decreasing reef channel spacing but is largely not impacted by reef roughness. Re-

29 entrainment was correlated with a predictor variable $R$, which is a measure of wave forcing

30 versus the total offshore flow cross-section, and alongshore currents outside the reef. For

31 large values of $R$ and strong alongshore currents, flow re-entrainment increases the effective

32 flushing time by a factor of three or more. The results suggest that flow re-entrainment may

33 be particularly important in small-scale reef systems or reefs exposed to an energetic wave

34 climate and/or strong alongshore currents.

\section{Keywords:}

36 Reef, wave-driven circulation, flushing, Lagrangian, drifter 


\section{Introduction}

The circulation of water within reef systems controls the exchange of dissolved and particulate material between reefs and the surrounding deeper ocean, which substantially influences ecosystems of both tropical coral reefs [see Lowe and Falter, 2015 for a review] and temperate rocky reefs [e.g. Morgan et al., 2016]. For example, the influx of water to reefs from the surrounding ocean often has higher nutrient concentrations and is cooler [Lowe and Falter, 2015]. As the water flows over shallow reefs, nutrients in various forms are taken up by reef communities at rates influenced by local water motion [Falter et al., 2004].

Furthermore, this influx of water contributes to the regulation of reef water temperatures, which due to the relatively shallow water depths, can either heat or cool relative to the surrounding ocean [Zhang et al., 2013]. Water that exits through the reef channel can also remove suspended sediments [e.g. Storlazzi et al., 2004], larvae [e.g. Lugo-Fernández et al., 2001] as well as pollutants from the reef system (e.g., associated with terrestrial discharge). [Black et al., 1990], buoyancy differences [Herdman et al., 2015], wind stresses [Tartinville et al., 1997] and breaking waves [Hoeke et al., 2011; Lowe et al., 2009; Taebi et al., 2011]. However, many reef systems that fringe coastlines are exposed to wind (sea-swell) wave energy that provides the main forcing to reef circulation. For these wave-exposed reefs, radiation stress gradients [Longuet-Higgins, 1962] that originate from wave dissipation on the forereef or reef crest generate variations in the mean water level over the reef flat and crossreef currents. In the absence of reef channels (i.e., a one-dimensional, cross-shore system) the setup over a coastal reef is maximum near the shoreline and the net depth-averaged cross-reef mass flux is zero [Buckley et al., 2016; Vetter et al., 2010]. When the reef flat is intersected by reef channels, the net forcing, which is the residual difference between radiation stress and setup gradients, drives a net cross-reef onshore flow that is countered by bed friction 
62 [Symonds et al., 1995]. The return flow in the channel may also be fed directly by alongshore

63 flows entering the channel laterally from the reef platform. The relative contribution of water

64 entering the channel from the lagoon or directly from the reef depends on the relative

65 importance of flow resistance across the reef and along the lagoon, which is governed by the

66 roughness properties as well as geometry of the reef system [Monismith, 2013].

In many reef studies, water that exits through a reef channel is assumed to leave the reef system and to be replaced by 'new' offshore water [Herdman et al., 2015; Lowe et al., 2010; Taebi et al., 2011]. While this approach allows ocean-reef exchange rates to be more easily quantified from fixed (Eulerian) measurements, it does not account for water that has initially flowed out through the channel and then returns back into the reef-lagoon system, which will effectively increase the flushing time of the system. While water exchange and flow re-entrainment in wave-dominated reefs have been previously estimated from numerical simulations, these have typically been done for either a specific reef system [e.g. Zhang et al., 2013] or for cases where the wave forcing was not modeled explicitly [e.g. Herdman, 2012]. Thus, a systematic approach to flow re-entrainment in wave-dominated reef environments that incorporates the impact of different oceanic forcing and reef geometry is currently lacking and motivates the present study.

The aim of this manuscript is to identify the parameters that govern flow reentrainment in wave-dominated coastal reef systems. To assess the hydrodynamic response to different parameters, we validate the numerical model XBeach [Roelvink et al., 2009] with field observations from moored instruments and Lagrangian drifters in a coastal reef system.

83 The model is then extended to test the effects of wave forcing and along-shelf currents as well as geometric parameters on flow re-entrainment in an idealized wave-dominated reef system. The specific objectives of this study are to: (i) investigate the variability of flow reentrainment, (ii) identify the governing parameters that drive this variability and (iii) to assess 
the implications of variable flow re-entrainment on flushing time estimates for coastal reef systems, more generally. The results can thus help to classify coastal reef systems as being predominantly open or closed systems [Cowen et al., 2000] based on their specific geometrical characteristics and predominant forcing.

Section 2 provides background on water exchange processes between the nearshore and the open ocean and explains different methods to quantify these exchange processes. Section 3 describes the field experiment and observations. In section 4 we present a numerical model of the field site that has been used to test the sensitivity of flow reentrainment to variable hydrodynamic forcing and reef geometry in a simplified reef system. Section 5 discusses the physical processes that change with the tested parameters and the impact of the re-entrainment rate on flushing time estimates.

\section{Background: Quantifying water exchange rates}

Water exchange between a coastal basin (e.g., an estuary or lagoon) and the surrounding open ocean is typically quantified in terms of a flushing time. This time scale is often estimated as the average time $\left(T_{f}\right)$ it takes for the entire volume $(V)$ of water inside the basin to be replaced by 'new' water and can be estimated as [Fischer et al., 1979]:

$$
T_{f}=\frac{V}{Q}
$$

where $Q$ is the flux of water into the basin. Importantly, Eq. (1) assumes that the outflow from an enclosed water body is not re-entrained once it exits the basin through defined boundaries [Monsen et al., 2002].

For tidally-flushed systems, Eq. (1) has been extended to include a re-entrainment fraction $b$ that accounts for water that exits the basin and subsequently re-enters the system at a later time [Sanford et al., 1992]: 


$$
T_{f}=\frac{V}{(1-b) Q}
$$

109 In prior studies of reef systems, re-entrainment is usually assumed to be zero $(b=0$ in Eq.

110 (2)) [Coronado et al., 2007; Kench, 1998; Kraines et al., 1999; Lowe et al., 2010; Taebi et

111 al., 2011]. Such a flushing time will therefore represent the minimum time for flushing to

112 occur. However, Herdman [2012] found re-entrainment rates in a large-scale tropical coral

113 reef system in Moorea (Polynesia), where circulation is driven by buoyancy and waves, to be

$11423-50 \%$ suggesting that re-entrainment would substantially increase the true flushing time.

Accurate estimates of $b$ in Eq. (2) can be difficult to obtain in the field because flow

116 re-entrainment can only be directly measured in a Lagrangian reference frame where flow

117 pathways are tracked. To overcome this, it is common to evaluate re-entrainment using

118 Lagrangian approaches (such as GPS-tracked drifters or dye), which has been frequently

119 applied in the study of rip currents along beaches [Austin et al., 2010; Brown et al., 2015;

120 Hally-Rosendahl et al., 2014; MacMahan et al., 2010b; $R$ Jak McCarroll et al., 2018; Reniers

121 et al., 2009; Spydell et al., 2007]. These sandy beach environments are often characterized by

122 having shore-parallel sand bars, over which water moves shoreward, and defined channels,

123 through which water returns seaward [Castelle et al., 2016; Dalrymple et al., 2011]. In these

124 studies, the cross-shore exchange has typically been expressed in terms of an exit rate (or its

125 opposite property, the retention rate). This exit (or retention) rate is defined by the number of

126 drifters leaving (or remaining within) the surf zone indefinitely, relative to the total number

127 of drifters initially seeded [Reniers et al., 2009]. Thus, drifters that recirculate and ultimately

128 remain inside the surf zone are accounted for in this definition. In beach environments, the

129 exit rate has been found to correlate with the so-called 'exit parameter', which is a function of

130 the surf zone width and the incident wave forcing [Reniers et al., 2009]. This exit rate can be

131 enhanced by geomorphic features such as headlands [Castelle and Coco, 2013; R. Jak 
132 McCarroll et al., 2014] and by intermittendly spaced rip channels and rip head shoals

133 [Castelle et al., 2014], but can be reduced due to the presence of alongshore currents and

134 obliquely incident waves [Spydell, 2016; Winter et al., 2014].

While the nearshore circulation patterns of barred beaches have some analogies to the

136 flows in fringing reef systems, there can be a number of key differences, for example: (1) reef

137 systems can have much larger spatial scales [see Falter et al., 2013], so that the impact of

138 parameters that describe the reef geometry, such as channel spacing, may differ; (2) bed

139 roughness over reefs [Reidenbach et al., 2006] as well as bathymetry gradients are often

140 much greater than over sandy bottoms; and (3) incident waves break on a forereef, which has

141 typically a steeper slope than a sandy beach, so that the width of the surf zone can be much

142 narrower and less variable [Symonds et al., 1982]. It remains unclear how these differences

143 will affect ocean-reef water exchange rates.

\section{Field Experiment}

\subsection{Site description}

A two-week field study was conducted during the austral winter (May-June) of 2014

147 along a $600 \mathrm{~m}$ stretch of Garden Island in southwestern Australia (Figure 1a). The beach is

148 fronted by several $\sim 1$ m deep limestone reefs, which is typical for much of the southwest

149 coast of Australia. A shore-attached reef platform is located near the center of the site and is

150 flanked to the south by another reef and by a deeper (2-3 m) lagoon (Figure 1c). To the north this group of reef platforms is bounded by a channel and to the south by a more pronounced and deeper channel, which is orientated in a southwesterly direction. The bathymetry of the region was surveyed in 2009 using aerial bathymetric LiDAR with 5 m horizontal resolution

154 and \pm 0.45 m uncertainty in the vertical [Department of Transport Western Australia, 2009].

155 In addition, a detailed bathymetric survey was conducted during the experiment using a 
156

157

158

159

160

161

162

single beam echosounder and RTK-GPS system by small boat and a backpack mounted

RTK-GPS system near the shoreline with an estimated uncertainty in the vertical of $0.1 \mathrm{~m}$ for surveys by boat [MacMahan, 2001] and $0.05 \mathrm{~m}$ by foot, respectively [Barnard et al., 2012].

The dimensions of the reef platforms and the lagoon are typical of many rocky coastlines as well as many nearshore fringing coral reefs, but smaller than those of some previously

studied coral reef systems [e.g. Herdman, 2012; Zhang et al., 2012]. The effect of reef scale on flow re-entrainment is discussed in section 5.1.3.

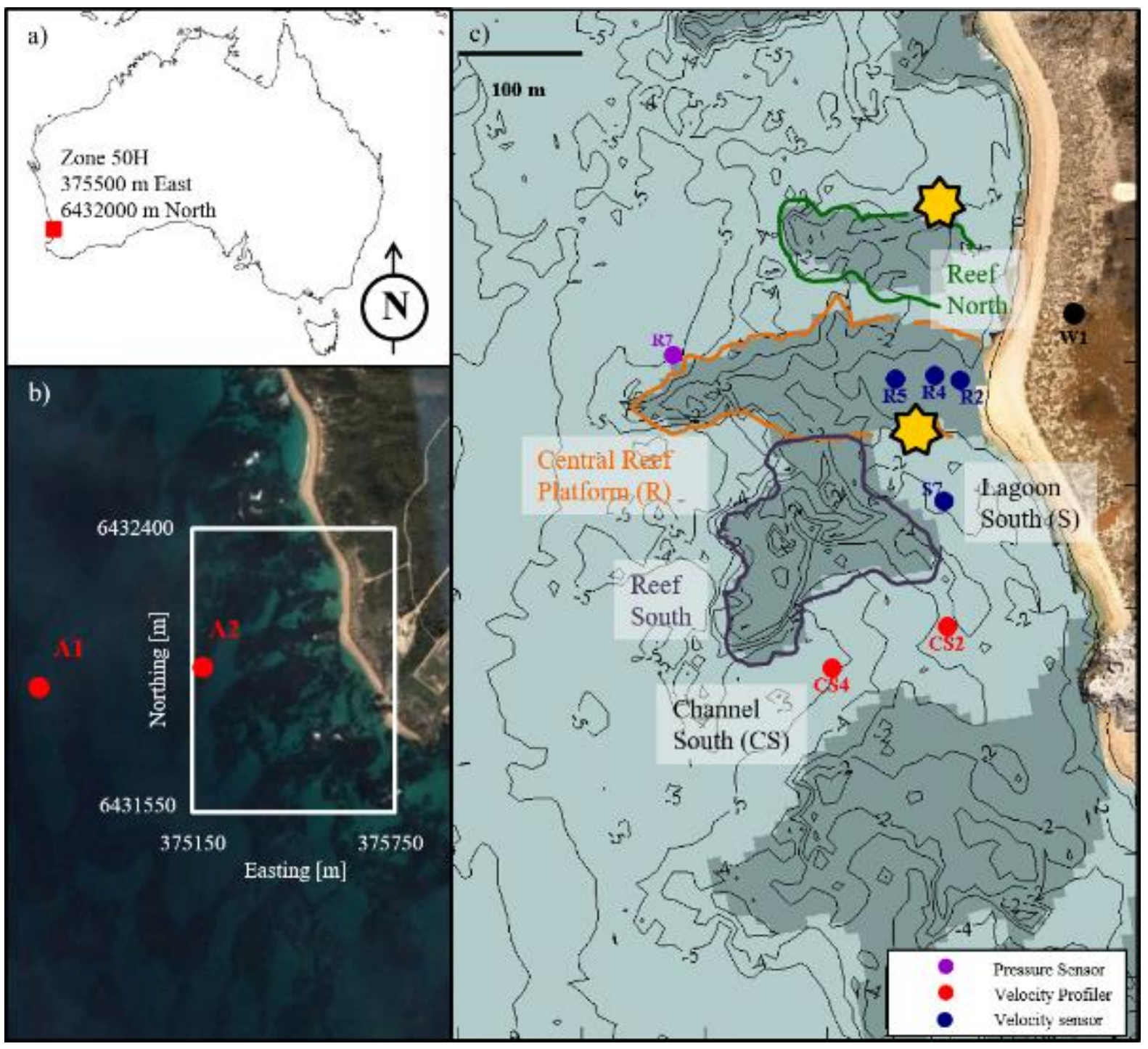

Figure 1. a) Location of the Garden Island study site within southwestern Australia, b) aerial image (Google Earth) of the field site and the locations of the Acoustic Wave and Current meters (AWAC) A1 and A2, c) locations of velocity profilers (red dots), velocimeters (blue 
dots) and the anemometer (black dot) as well as drifter release locations in the southern and northern channel (stars). Dark shaded areas in c) indicate submerged reef structures. experiment the tidal range was between 0.3 and $0.6 \mathrm{~m}$ so that tidally induced currents are negligible. Alongshore currents outside the reef on the inner continental shelf (depth up to 20 m) are predominantly driven by a balance between local wind stresses and regional

167 alongshore pressure gradients [Zaker et al., 2007]. The currents can become particularly strong (up to $0.3 \mathrm{~m} \mathrm{~s}^{-1}$ ) during the summer months due to persistent southwesterly winds [Gersbach et al., 1999]. Episodic fluctuations in the shelf-scale pressure gradients due to coastally trapped waves and eddies can enhance the variability, and episodically reverse the along- and cross-shore currents on the inner shelf [Ruiz-Montoya and Lowe, 2014]. Section southwest coast of Australia receives the highest wave energy events in the austral winter months from May to September [Bosserelle et al., 2012] in the period that the experiment took place.

\subsection{Instrument Layout}

Surf zone exit and re-entrainment rates were quantified using Lagrangian drifters,

178 similar to the design by Schmidt et al. [2003], over 8 days during the experiment. When

179 floating freely, all but the uppermost $\sim 5 \mathrm{~cm}$ of the drifter bodies were submerged. Based on a

180 similar drifter design, wind drift was estimated at $1 \%$ of the wind speed measured $0.5 \mathrm{~m}$

181 above the water surface [Schmidt et al., 2003] and therefore is not expected to affect the

182 drifters during this experiment (expected drift due to windage $<0.05 \mathrm{~ms}^{-1}$ ). Drifter positions

183 were recorded at $10 \mathrm{~Hz}$ by a Qstarz BT-Q1000eX GPS logger placed in the top of each

184 drifter. For each of the 8 deployment days, 12 to 15 drifters were released for two to four

185 hours at a time (Table 1). Drifters were deployed in clusters, mostly inside the southern 
186 lagoon ( 8 of the 11 deployments), with the remaining deployments inshore of the northern

187 channel (yellow stars in Figure 1c). This manuscript focuses primarily on the deployments in

188 the southern lagoon because the lagoon connects to the better defined southern channel.

189 During each deployment, any drifters that beached or exited the reef-system were retrieved

190 and redeployed at the initial release location. Data recorded by the GPS loggers were initially

191 averaged in $1 \mathrm{~Hz}$ blocks to remove noise. Short wave motions were then removed by

192 applying a moving average filter of 25 s so that only infragravity and slowly varying mean

193 current motions were preserved in the recorded drifter tracks. The low-pass filtered positions

194 were numerically-differentiated to determine the velocities of the drifters. The velocity and

195 vorticity of all drifter observations was averaged over cells of $20 \mathrm{~m}$ by $20 \mathrm{~m}$.

Table 1. Drifter deployments: Number of drifters deployed on each day, total duration of each drifter deployment, offshore wave conditions, observed return flow regime (only in the southern channel) and deployment location.

\begin{tabular}{|c|c|c|c|c|c|c|c|c|c|}
\hline Day & $\begin{array}{l}\text { Number } \\
\text { of } \\
\text { drifters }\end{array}$ & $\begin{array}{c}\text { Duration } \\
\text { (hours) }\end{array}$ & $\begin{array}{l}H_{m 0} \\
{[\mathrm{~m}]}\end{array}$ & $\begin{array}{l}T_{p} \\
{[\mathrm{~s}]}\end{array}$ & $\begin{array}{c}\theta_{p} \\
{\left[{ }^{\circ} \mathrm{N}\right]}\end{array}$ & $\begin{array}{c}\text { Water } \\
\text { depth } \\
\text { on the } \\
\text { reef } \\
{[\mathrm{m}]}\end{array}$ & $\begin{array}{l}\text { Along- } \\
\text { shelf } \\
\text { current } \\
{\left[\mathrm{m} \mathrm{s}^{-1}\right]}\end{array}$ & $\begin{array}{l}\text { Return flow } \\
\text { regime in } \\
\text { the southern } \\
\text { channel }\end{array}$ & $\begin{array}{l}\text { Deployment } \\
\text { location }\end{array}$ \\
\hline 1 & 12 & $3: 40$ & 1.66 & 14 & 266 & 1.00 & 0.04 & $\begin{array}{l}\text { Re- } \\
\text { entrainment }\end{array}$ & $\begin{array}{l}\text { Southern } \\
\text { lagoon }\end{array}$ \\
\hline 2 & 15 & $4: 24$ & 1.49 & 13 & 265 & 0.99 & 0.05 & $\begin{array}{l}\text { Re- } \\
\text { entrainment }\end{array}$ & $\begin{array}{l}\text { Southern } \\
\text { lagoon }\end{array}$ \\
\hline 3 & 15 & $2: 28$ & 1.48 & 14 & 262 & 0.96 & -0.02 & Combination & $\begin{array}{l}\text { Southern } \\
\text { lagoon and } \\
\text { northern } \\
\text { channel }\end{array}$ \\
\hline 4 & 15 & $1: 46$ & 1.24 & 14 & 268 & 1.21 & -0.06 & Exiting & $\begin{array}{l}\text { Southern } \\
\text { lagoon }\end{array}$ \\
\hline 5 & 15 & $2: 56$ & 1.31 & 13 & 261 & 1.21 & -0.1 & Exiting & $\begin{array}{l}\text { Southern } \\
\text { lagoon and } \\
\text { northern } \\
\text { channel }\end{array}$ \\
\hline 6 & 15 & $3: 58$ & 1.13 & 12 & 261 & 1.11 & -0.05 & $\begin{array}{l}\text { Re- } \\
\text { entrainment }\end{array}$ & $\begin{array}{l}\text { Southern } \\
\text { lagoon }\end{array}$ \\
\hline 7 & 15 & $3: 22$ & 1.24 & 18 & 267 & 1.09 & -0.05 & Exiting & $\begin{array}{l}\text { Southern } \\
\text { lagoon }\end{array}$ \\
\hline 8 & 14 & $2: 47$ & 1.40 & 15 & 266 & 1.06 & -0.02 & $\begin{array}{l}\text { Re- } \\
\text { entrainment }\end{array}$ & $\begin{array}{l}\text { Southern } \\
\text { lagoon and }\end{array}$ \\
\hline
\end{tabular}




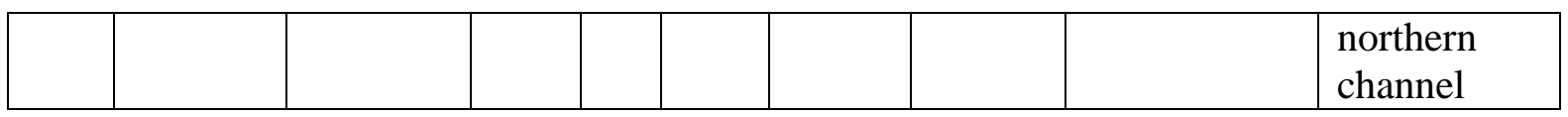

In addition to the drifters, acoustic Doppler velocimeters and profilers measured

197 velocities and wave conditions throughout the experiment at six sites within the reef-lagoon

198 system (Table 2 and Figure 1c). For instruments in the shallow reef-lagoon system (depths <5

$199 \mathrm{~m})$, the velocities were low-pass filtered to remove fluctuations shorter than 15 minutes, and

200 in the case of the velocity profilers, the velocities were depth-averaged. On the inner shelf

201 (site A1 in $11 \mathrm{~m}$ water depth, Figure 1b), an Acoustic Wave and Current meter (AWAC)

202 recorded offshore waves and currents. Drifter deployments were conducted at similar tidal

203 water levels of $0.25 \mathrm{~m}$ above Australian Height Datum (AHD, approximately mean sea level)

204 during falling tide (Figure 2a). During the deployments the incident significant wave heights

205 at A1 ranged from $H_{m 0}=1.0-1.8 \mathrm{~m}$, peak periods from $12-18 \mathrm{~s}$ and directions from $260-270^{\circ}$

206 (Figure 2b-d). At sites A1 and A2 the hourly mean velocities were averaged over the

207 uppermost $1.5 \mathrm{~m}$ of the water column, where they were usually strongest. At site A1, the

208 surface currents varied between $-0.1 \mathrm{~m} \mathrm{~s}^{-1}$ and $0.05 \mathrm{~m} \mathrm{~s}^{-1}$ during the deployments (Figure 2e).

Table 2. Instruments and sampling configuration. "A" denotes offshore instruments, "CS" instruments in the southern respectively, " $\mathrm{R}$ " instrument on the reef platform and " $\mathrm{S}$ " south of it.

\begin{tabular}{|c|c|c|c|c|c|c|}
\hline Site & $\begin{array}{l}\text { Instrumen } \\
\mathrm{t}\end{array}$ & Depth & $\begin{array}{l}\text { Sampling } \\
\text { configurations }\end{array}$ & $\begin{array}{l}\mathrm{H}_{\mathrm{m} 0} \\
\text { (RMSE, } \\
\text { bias, } \\
\text { WS) }\end{array}$ & $\begin{array}{l}\mathrm{u} \\
\text { (RMSE, } \\
\text { bias, } \\
\text { WS) }\end{array}$ & $\begin{array}{l}\mathrm{V} \\
(\mathrm{RMSE}, \\
\text { bias, } \\
\text { WS) }\end{array}$ \\
\hline \multicolumn{7}{|c|}{ Offshore } \\
\hline A1 & $\begin{array}{l}\text { Nortek } \\
\text { AWAC }\end{array}$ & $10.5 \mathrm{~m}$ & \multicolumn{4}{|c|}{$\begin{array}{l}\text { Pressure and surface velocities in hourly bursts of } 2048 \mathrm{~s} \text { at } \\
2 \mathrm{~Hz} \text {, velocity profile hourly in } 0.5 \mathrm{~m} \text { bins }\end{array}$} \\
\hline \multicolumn{7}{|c|}{ Within the reef-lagoon system } \\
\hline CS2 & $\begin{array}{l}\text { Nortek } \\
\text { ADP High } \\
\text { Resolutio } \\
\text { n (HR) }\end{array}$ & $3.1 \mathrm{~m}$ & $\begin{array}{l}\text { Pressure and } \\
\text { velocity profile at } 1 \\
\text { Hz continuous in } \\
0.05 \text { m bins }\end{array}$ & $\begin{array}{l}0.42 \mathrm{~m} \\
0.42 \mathrm{~m} \\
0.58\end{array}$ & $\begin{array}{l}0.02 \mathrm{~m} \mathrm{~s}^{-1}, \\
0.00 \mathrm{~m} \mathrm{~s}^{-1} \\
0.95\end{array}$ & $\begin{array}{l}0.11 \mathrm{~m} \mathrm{~s}^{-1}, \\
-0.11 \mathrm{~m} \mathrm{~s}^{-1}, \\
0.86\end{array}$ \\
\hline CS4 & $\begin{array}{l}\text { RDI } \\
\text { ADCP }\end{array}$ & $5.4 \mathrm{~m}$ & $\begin{array}{l}\text { Pressure and } \\
\text { velocity profile at } 1\end{array}$ & $\begin{array}{l}0.35 \mathrm{~m}, \\
0.35 \mathrm{~m}, \\
0.64\end{array}$ & $\begin{array}{l}0.06 \mathrm{~m} \mathrm{~s}^{-1}, \\
0.05 \mathrm{~m} \mathrm{~s}^{-1}, \\
0.90\end{array}$ & $\begin{array}{l}0.11 \mathrm{~m} \mathrm{~s}^{-1}, \\
-0.11 \mathrm{~m} \mathrm{~s}^{-1}, \\
0.88\end{array}$ \\
\hline
\end{tabular}




\begin{tabular}{|c|c|c|c|c|c|c|}
\hline & & & $\begin{array}{l}\mathrm{Hz} \text { continuous in } \\
0.1 \mathrm{~m} \text { bins }\end{array}$ & & & \\
\hline $\mathrm{R} 2$ & $\begin{array}{l}\text { Nortek } \\
\text { ADV }\end{array}$ & $1.2 \mathrm{~m}$ & $2 \mathrm{~Hz}$ continuous & $\begin{array}{l}0.08 \mathrm{~m}, \\
-0.07 \mathrm{~m}, \\
0.91\end{array}$ & $\begin{array}{l}0.08 \mathrm{~m} \mathrm{~s}^{-1}, \\
-0.07 \mathrm{~m} \mathrm{~s}^{-1}, \\
0.90\end{array}$ & $\begin{array}{l}0.09 \mathrm{~m} \mathrm{~s}^{-1}, \\
0.08 \mathrm{~m} \mathrm{~s}^{-1}, \\
0.90\end{array}$ \\
\hline R4 & $\begin{array}{l}\text { Nortek } \\
\text { ADV }\end{array}$ & $1.0 \mathrm{~m}$ & $2 \mathrm{~Hz}$ continuous & $\begin{array}{l}0.04 \mathrm{~m}, \\
-0.02 \mathrm{~m}, \\
0.97\end{array}$ & $\begin{array}{l}0.12 \mathrm{~m} \mathrm{~s}^{-1}, \\
-0.10 \mathrm{~m} \mathrm{~s}^{-1}, \\
0.84\end{array}$ & $\begin{array}{l}0.13 \mathrm{~m} \mathrm{~s}^{-1}, \\
0.12 \mathrm{~m} \mathrm{~s}^{-1}, \\
0.85\end{array}$ \\
\hline R5 & $\begin{array}{l}\text { Nortek } \\
\text { ADV }\end{array}$ & $1.2 \mathrm{~m}$ & $2 \mathrm{~Hz}$ continuous & $\begin{array}{l}0.09 \mathrm{~m}, \\
-0.09 \mathrm{~m}, \\
0.91\end{array}$ & $\begin{array}{l}0.13 \mathrm{~m} \mathrm{~s}^{-1} \\
-0.07 \mathrm{~m} \mathrm{~s}^{-1} \\
0.78\end{array}$ & $\begin{array}{l}0.12 \mathrm{~m} \mathrm{~s}^{-1}, \\
0.10 \mathrm{~m} \mathrm{~s}^{-1}, \\
0.86\end{array}$ \\
\hline R7 & $\begin{array}{l}\text { RBR } \\
\text { Virtuoso }\end{array}$ & $5.2 \mathrm{~m}$ & $1 \mathrm{~Hz}$ continuous & $\begin{array}{l}0.13 \mathrm{~m}, \\
0.11 \mathrm{~m}, \\
0.92\end{array}$ & - & - \\
\hline S7 & $\begin{array}{l}\text { Nortek } \\
\text { ADV }\end{array}$ & $2.3 \mathrm{~m}$ & $2 \mathrm{~Hz}$ continuous & $\begin{array}{l}0.13 \mathrm{~m}, \\
0.12 \mathrm{~m}, \\
0.82\end{array}$ & $\begin{array}{l}0.05 \mathrm{~m} \mathrm{~s}^{-1}, \\
0.05 \mathrm{~m} \mathrm{~s}^{-1}, \\
0.93\end{array}$ & $\begin{array}{l}0.05 \mathrm{~m} \mathrm{~s}^{-1}, \\
-0.03 \mathrm{~m} \mathrm{~s}^{-1}, \\
0.95\end{array}$ \\
\hline \multicolumn{7}{|c|}{ On land } \\
\hline W1 & \multicolumn{2}{|c|}{$\begin{array}{l}\text { Young Ultrasonic } \\
\text { Anemometer } 85106\end{array}$} & \multicolumn{4}{|l|}{$10 \mathrm{~s}$ average } \\
\hline
\end{tabular}

Wind was measured on the dune near the salient with an ultrasonic anemometer

211 (Young 85106) that sampled average wind speeds at $10 \mathrm{~s}$ intervals. This anemometer did not

212 sample continuously due to power interruptions and missing data were filled in by wind

213 speeds and directions sampled half-hourly $700 \mathrm{~m}$ inland from the field site [Bureau of

214 Meterology Commonwealth of Australia, 2014]. In the overlapping periods, the locally

215 measured wind data correlated well with the inland measurements $\left(R^{2}=0.90\right.$ and $R^{2}=0.94$

216 for cross-shore and alongshore wind speeds, respectively). During the deployments, wind

217 speeds varied between $2-5 \mathrm{~m} \mathrm{~s}^{-1}$ and came from a range of directions (Figure 2f). 

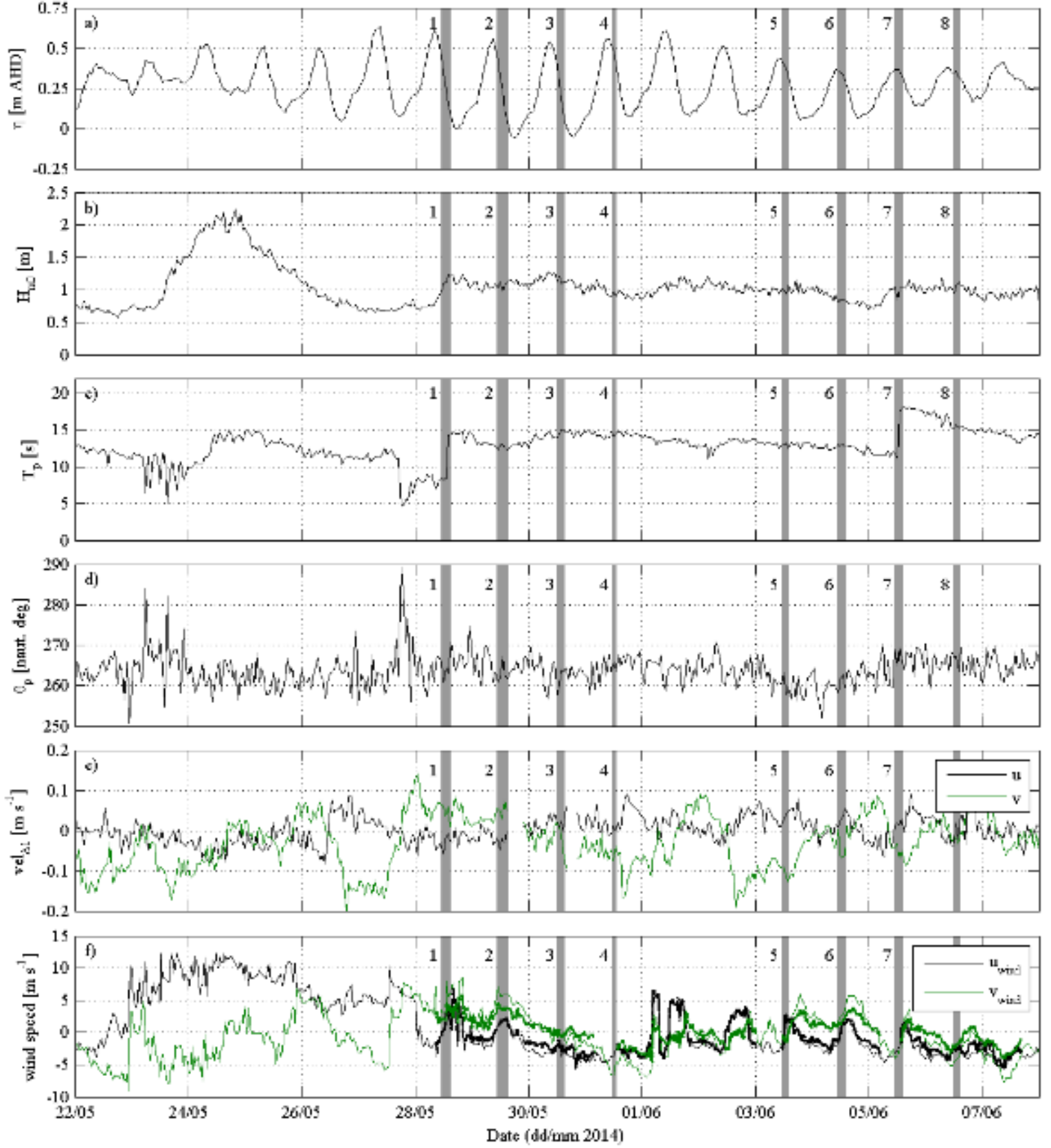

218 Figure 2. Site A1: a) Tidal water level relative to AHD, b) significant wave height at, c) peak

219 wave period at A1, d) peak wave direction at A1, e) cross- and alongshore currents in the

220 most upper $1 \mathrm{~m}$ of the water column at A1. Site W1: f) cross-shore and alongshore wind

221 speed measured at W1 (thick lines) and by the Bureau of Meterology Commonwealth of

222 Australia [2014] (thin lines). Positive cross-shore $(u)$ and alongshore $(v)$ velocities are

223 directed shoreward and northward, respectively. Grey shaded areas denote the times of drifter releases and the numbers from 1 to 8 denote the day of drifter deployment. See Figure 1 for 
225 the locations of sites A1 and W1.

\section{$226 \quad 3.3$ Quantifying re-entrainment}

To provide a quantitative measure of flow re-entrainment, we evaluated the exchange rate between lagoon and ocean waters using two different definitions of the exit rate, based on either excluding or including the effect of re-entrainment. Both these exit rates were

230 calculated for the drifters deployed in the field as well as those simulated in the numerical model XBeach (Section 4). The first exit rate $E_{l}$ is based on the commonly used minimum flushing time described by Eq. (1) and is defined as the ratio of the number of drifters that leave the reef-lagoon system in seaward direction $(L)$ and the total number of drifters initially

234 seeded $(N)$, i.e.

$$
E_{1}=\frac{L}{N}
$$

235 The offshore boundary of the reef-lagoon system is defined as the cross-shore position where

236 the alongshore-averaged roller energy (as calculated in XBeach) exceeded $10 \%$ of the

237 maximum roller dissipation in accordance with studies on rip-channeled beaches [e.g.

238 Reniers et al., 2009].

The second exit rate definition $\left(E_{2}\right)$ accounts for re-entrainment and thus corresponds to a more realistic estimate of the amount of flushing. The exit rate $E_{2}$ is defined as the ratio

241 of drifters retrieved outside the reef-lagoon system at the end of the deployment over the total

242 number of drifters released within the reef system $(N)$. The total number of drifters outside

243 the reef-lagoon system is the difference between the number of drifters that left the lagoon

244 seaward through the channel $(L)$ and the number of drifters that return back to the reef-lagoon $245 \quad \operatorname{system}(B)$ : 


$$
E_{2}=\frac{L-B}{N}
$$

246 This definition is similar to the definition used in surf zone exchange studies on beaches

247 [MacMahan et al., 2010a]. When the drifters were released, the number of drifters outside the 248 reef-lagoon system $\left(E_{2}\right)$ typically increased and then fluctuated around a constant value (see,

249 for example, Figure 4, Day 1 and 6). These fluctuations were related to groups of drifters

250 simultaneously exiting and re-entering the lagoon. We note that this exit rate definition $E_{2}$

251 does not distinguish between re-entrained drifters and drifters that remained inside the reef-

252 lagoon system, i.e. there is no difference between low exchange rates due to stagnant flow

253 and due to energetic recirculating flow [similar to the residence time approach in Zhang et

$254 a l ., 2012] . E_{2}$ is thus not a suitable measure to quantify the return flow regime of water that

255 exits the channel.

A parameter that specifically describes the return flow regime is the flow re-

entrainment $b$ (Eq. (2)), which is defined as the number of drifters re-entering the lagoon $(B)$

divided by the number of drifters that have exited the channel $(L)$, and was quantified by

combining Eqs. (3) and (4):

$$
b=\frac{B}{L}=\frac{E_{1}-E_{2}}{E_{1}}
$$

260 We note that water exiting the channel may be mixed with the surrounding ocean water

261 through lateral dispersion and that $b$ may also be smaller than estimated from Lagrangian

262 drifter measurements or simulations. Numerical modelling indicates that sub-grid mixing

263 using the Smagorinsky [1963] model accounted for less than 5\% in the momentum balance

264 equation and was negligible. Hence, advection is the dominant process to transport material 265 offshore or to re-entrain it back into the reef-lagoon system. 


\subsection{Field Observations}

269 (Figure 3c and d), and a combination of pattern (i) and (ii).
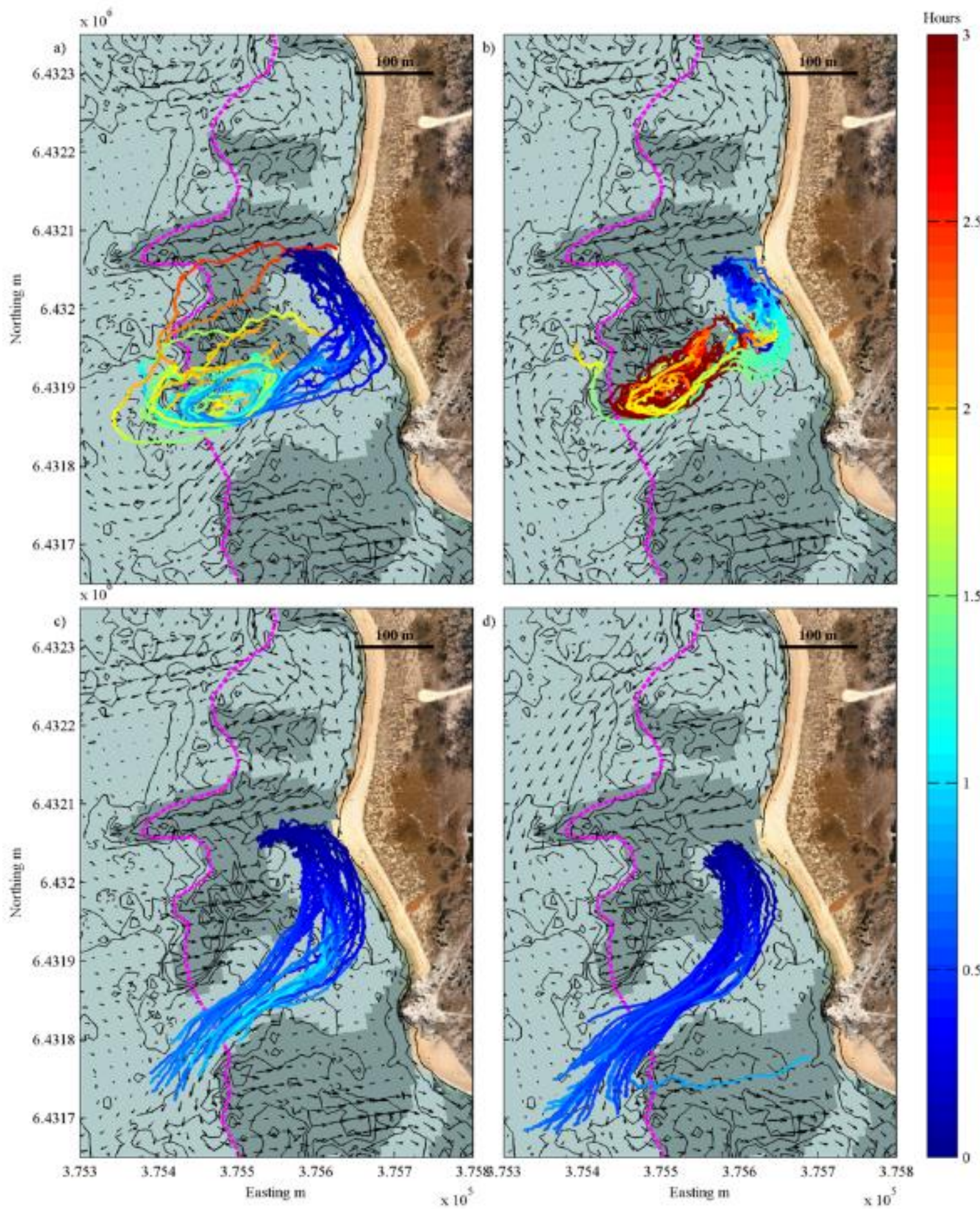

Figure 3. Examples of observed drifter trajectories that become re-entrained on a) Day 1 and 
b) Day 2 and drifters that exit the reef system on c) Day 5 and d) Day 7. The colors indicate time in hours since individual drifter deployment and the vectors are mean velocities obtained from the model. The pink line marks the outer edge of the surf zone defined as the crossshore position where the roller energy exceeds $10 \%$, which was derived from the XBeach results. The surf zone has been interpolated across the channels where no wave breaking occurred.

In flow pattern (i), drifters released in the southern lagoon drifted southward parallel to the shore, turned sharply seaward in the middle of the embayment and then floated offshore along the edge of the channel. Most of the drifters turned north outside the channel and re-entered over the reef in a tight circulation cell. In flow pattern (ii), drifters floated seaward along the center of the channel and exited in a southwesterly direction. Drifters typically left the reef system within an hour or less after their deployment inside the southern lagoon (see colors in Figure 3c and d). In contrast, re-entrained drifters remained within the reef lagoon system for two hours or more (see colors in Figure 3a and b). We classified the eight drifter deployments into predominantly exit or re-entrainment flow patterns. Day 1, 2, 3, 6 and 8 were characterized by (partial) drifter re-entrainment. Initially, all drifters were seeded inside the reef-lagoon system (green areas, Figure 4). Drifters then exited the reef system (yellow) and re-entered so that at any point in time a proportion of drifters was inside and the remaining drifters were outside the reef-lagoon system. On Day 1, drifters circulated in a wide eddy so that at any given time $E_{2} \sim 50 \%$ of all drifters were offshore of the breaker zone (Figure 4). All of these drifters re-entered the lagoon and the re-entrainment rate $b$ was $100 \%$. On Day 2, drifters remained mostly onshore of the breaker line and thus $E_{2}$ was low

287 (10\%). Drifters were retrieved gradually inside the lagoon after circulating numerous times, hence the gradual decrease of total drifters. On Day 3, a large number of drifters $\left(E_{2}=76 \%\right)$ exited the reef-lagoon system indefinitely and only a small number of drifters $(b=26 \%)$ 
recirculated. Similarly, on Day 6 only $46 \%$ of the drifters were re-entrained. Exiting drifters were retrieved and redeployed again inside the lagoon so that the total number of drifters

294 left the reef system, mostly re-entered the lagoon and were retrieved both outside and inside the reef-lagoon system.
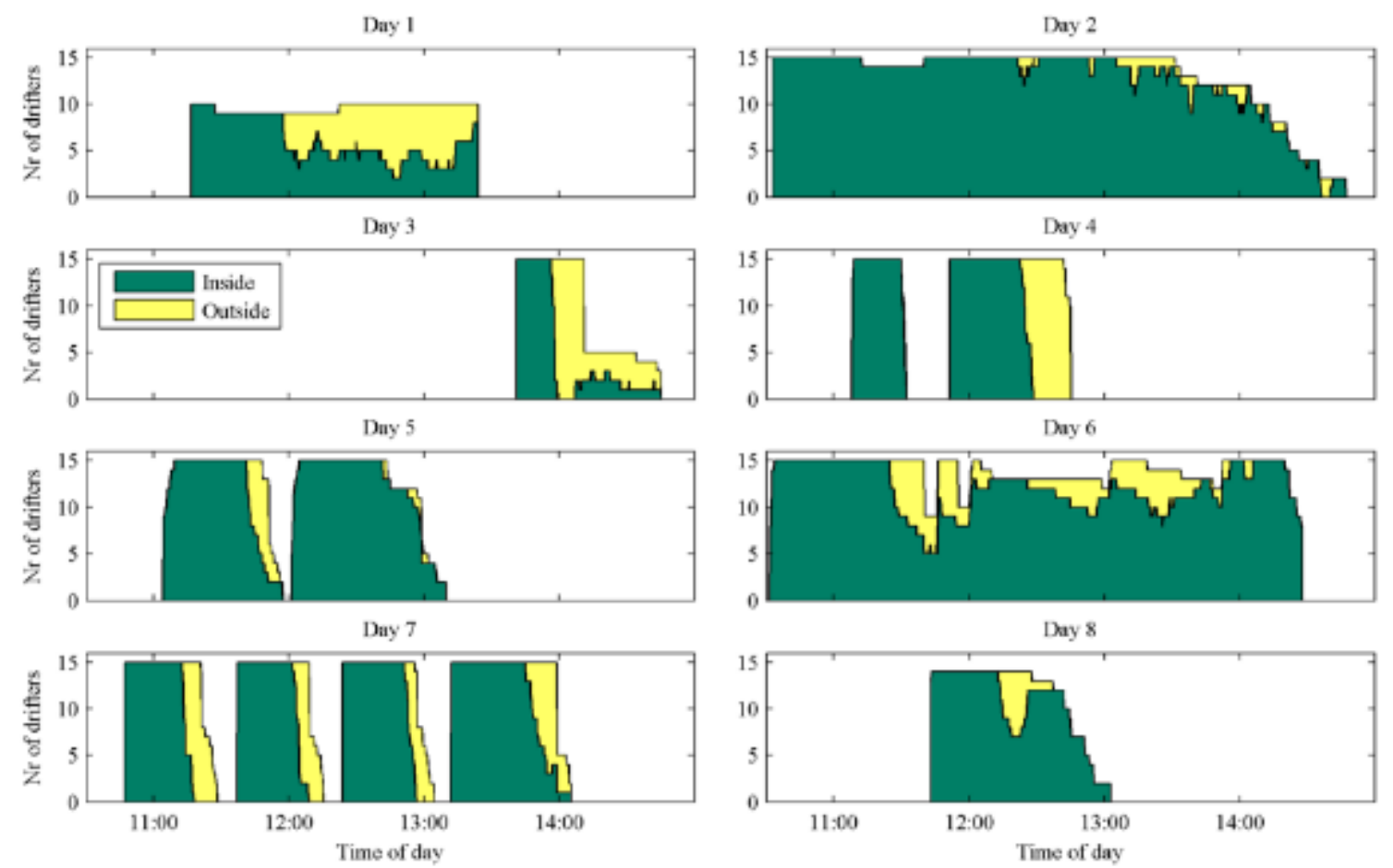

Figure 4. Number of drifters inside (green) and outside (yellow) the reef-lagoon system as a function of time for each day. Day 1, 2, 3, 6 and 8 were characterized by (partial) drifter reentrainment and Day 4, 5 and 7 by drifter exits.

In general, drifters were more likely to re-enter the lagoon when they floated alongside the channel edge where they were caught in an eddy (marked by the high vorticity in Figure 5a) than when they floated along the center of the channel in a south-westerly

300 direction (Figure 5b). The re-entrainment pattern was dominant when wave heights were

301 large, water levels were low and alongshore velocities were directed northward and thus 

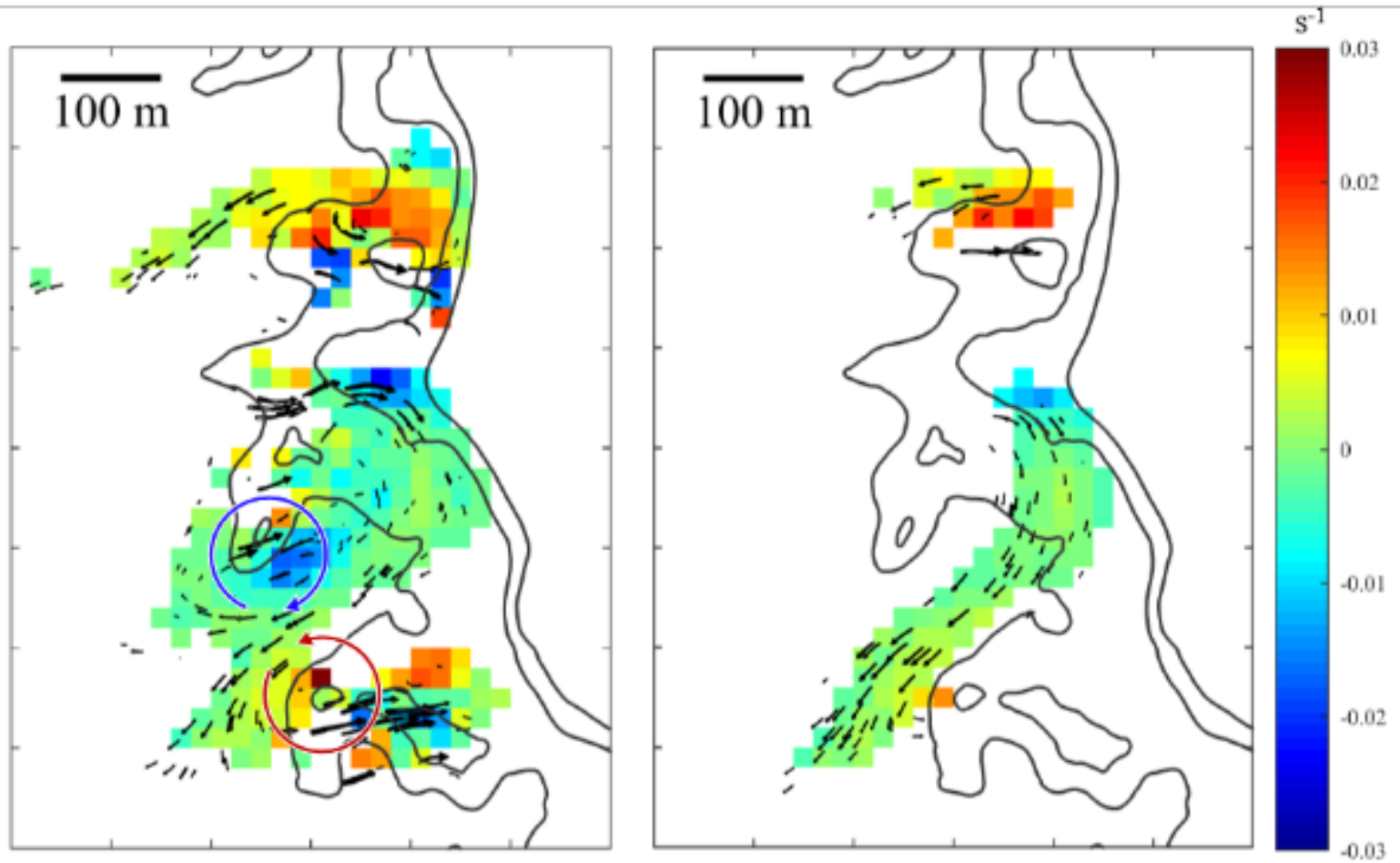

Figure 5. Drifter velocity (black arrows) and vorticity (colours) averaged over all drifter deployments, in which retention dominated (left) and in which exits dominated (right) interpolated on a $20 \mathrm{~m}$ x $20 \mathrm{~m}$ grid. Red (blue) circles in the left panel indicate eddies rotating in clockwise (anti-clockwise) direction. In the right panel, information on drifter velocity is mostly absent along the channel edges because drifters generally floated along the centre of the channel in exit dominated flow regimes.

The qualitative observations of drifter behavior and flow patterns over the course of the field experiment motivated a numerical sensitivity study of re-entrainment in an idealized reef to understand and predict the response to varying wave height, alongshore current and variable reef geometry (section 4.3). 


\section{Numerical Model}

309

310

311

312

313

314

315

316

317

\subsection{Model description}

The general influence of reef geometry parameters and offshore hydrodynamic conditions on water exchange rates were further investigated using the numerical model XBeach configured in a short wave-group (surf beat) mode (refer to Roelvink et al. [2009] for details of the model). This model couples a module describing the wave-group varying wave energy with a non-linear shallow water wave module to describe wave-averaged flow, including wave setup, infragravity waves and wave-current interactions, and has been successfully used in other two-dimensional reef studies [van Dongeren et al., 2013] as well as numerical experiments on drifter retention on rip channeled beaches [Castelle et al., 2014].

The analysis of the model output was conducted in two stages. Firstly, to gain confidence that the model is capable of accurately reproducing drifter exits and retention, we performed hindcast simulations of the drifter observations based on the bathymetry of the field site at Garden Island. The model was forced by JONSWAP spectra on the offshore boundary ( 11 m depth) that represented the significant wave height, peak period, directional and frequency spreading of the frequency-direction variance density spectra measured at the offshore AWAC A1 (Figure 1b). Bathymetry within the model domain was derived from the aerial LiDAR and single beam echosounder surveys. Wave breaking was simulated using the dissipation formulation proposed by Roelvink [1993] with $\gamma=0.7$, which is similar to previous reef hydrodynamic models [Lowe et al., 2010] and provided better results than other values of $\gamma$ tested in this study within the typical range from 0.5 to 0.7 [van Dongeren et al., 2013]. The wave forcing that generates wave setup and currents within the flow module included radiation stresses due to short waves and wave rollers. Sub-grid turbulence was modelled using the Smagorinsky [1963] turbulence closure model. The domain consisted of 
332190 grid cells in the alongshore by 103 cells in the cross-shore with a resolution of 6 x 6 m in

333 the areas of interest over the reef and in the lagoon. Each simulation was allowed one-hour

334 spin-up time, which was adequate to establish a steady state wave-driven reef circulation, and

335 the subsequent hourly output was used to calculate time-averaged flow and wave quantities.

336 For computational efficiency, the hindcasts were performed for specific one-hour periods

337 each day coinciding to daily maximum and minimum water levels (diurnal high and low tide)

338 as well as intermediate tide stages. This resulted in 64 hindcast simulations (four per day),

339 which were used to assess the model performance for variable wave and water level

340 conditions.

Bottom friction was modeled as [Feddersen et al., 2000; Ruessink et al., 2001]:

$$
\tau^{b}=c_{f} \rho \sqrt{\left(1.16 u_{r m s}\right)^{2}+\left(u_{E}+v_{E}\right)^{2}}
$$

342 where $\tau^{b}$ is the bottom friction, $\mathrm{c}_{f}$ is the depth-independent friction coefficient, $\rho$ the water

343 density, $u_{r m s}$ the root-mean-squared orbital wave velocity and $u_{E}$ and $v_{E}$ are the depth-

344 averaged cross-shore and alongshore velocities. Within the sandy areas (i.e. lagoon, channels

345 and offshore), we assumed that bed friction was comparable to typical values reported at

346 beaches using an equivalent friction formulation [Feddersen et al., 2000] and set the bed

347 friction coefficient to $\mathrm{c}_{f}=0.003$ [e.g. Feddersen et al., 1998]. Based on initial model testing

348 we calibrated the bed friction over the reef areas (darker shades in Figure 3 ) to $c_{f}=0.01$,

349 which is lower than values reported for coral reefs using an equivalent friction

350 parameterization (values have typically been found to range from $0.009-0.027$ over reefs; see

351 Table 1 in Rosman and Hench [2011]). This lower friction coefficient is conceivable for a

352 weathered limestone reef with algae cover. Wind stresses were applied in the model based on

353 the measured wind velocities and a quadratic wind drag coefficient of $C_{D}=0.002$ [Large and

354 Pond, 1981]. However, including wind forcing terms did not affect the model skill even 
355 during the storm event, when the wind speed exceeded $12 \mathrm{~m} \mathrm{~s}^{-1}$ because the wind stress terms were an order of magnitude smaller than the dominant wave and pressure forcing terms.

357 Along-shelf currents offshore of the reef were simulated by imposing an alongshore pressure gradient to reproduce the weak, moderate or strong north- or southward directed currents observed in the surface layer at A1.
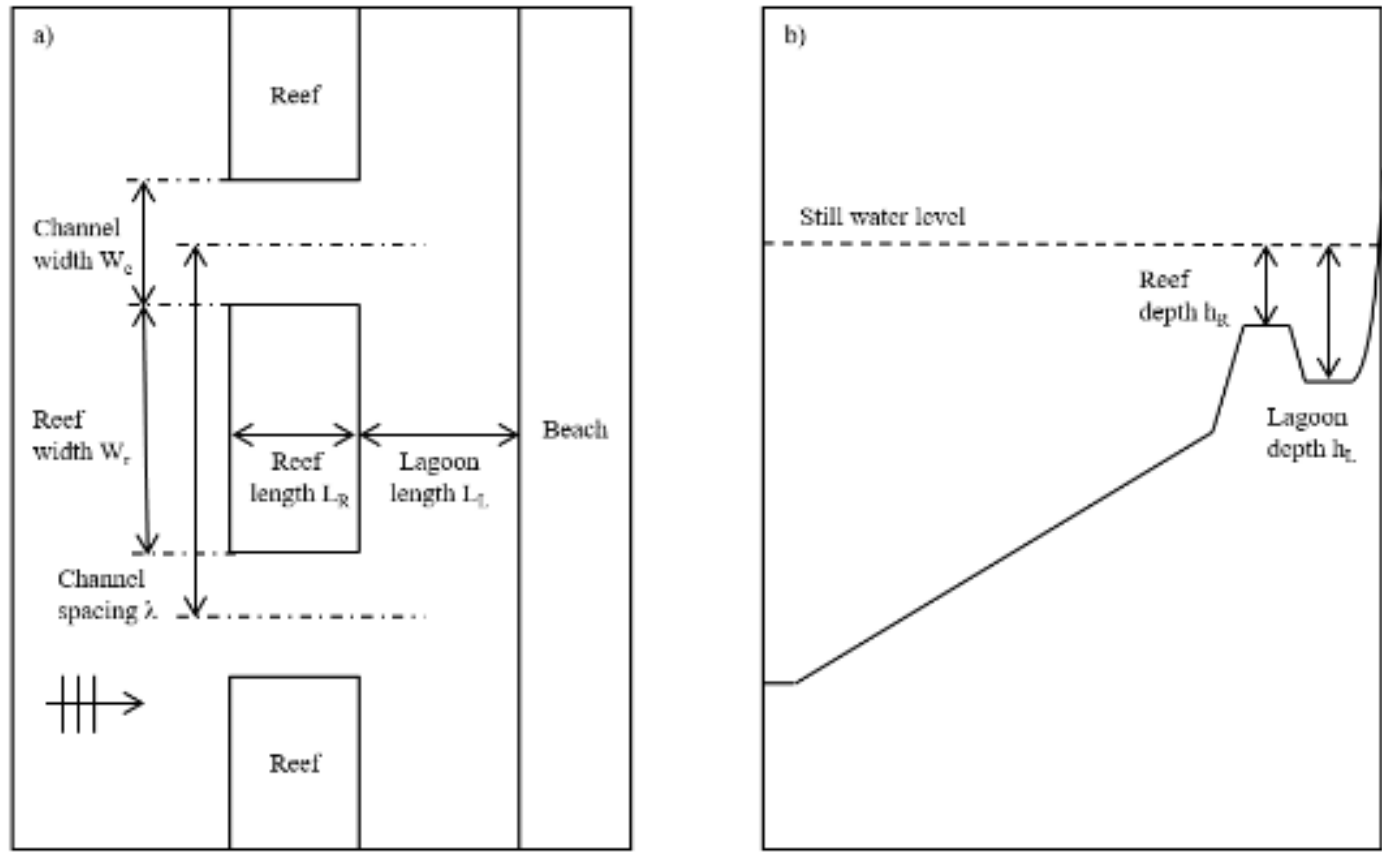

Figure 6. Schematized reef dimensions: a) top view and b) cross-sectional view. The default values for channel width, reef length and depth as well as lagoon length and depth were $W_{C}=100 \mathrm{~m}, L_{R}=150 \mathrm{~m}, h_{R}=1.5 \mathrm{~m}, L_{\text {Lag }}=150 \mathrm{~m}$ and $h_{\text {Lag }}=3 \mathrm{~m}$, respectively.

In the second stage of the analysis, we simplified the bathymetry to isolate the impact of various hydrodynamic parameters and reef geometries on flow re-entrainment. For this analysis, the bathymetry at Garden Island was schematized with rectangular reefs that were intersected by regularly spaced channels (Figure 6). This geometry was similar to the reeffringed lagoon to the south of the platform, where most of the drifters were deployed. In a series of simulations, parameters of the idealized reef system (channel spacing and reef 
370 friction) and hydrodynamic forcing (offshore wave height and along-shelf current) were co-

371 varied, while other parameters were kept constant. The model reef was $150 \mathrm{~m}$ wide in the

372 cross-shore and was located $150 \mathrm{~m}$ from the shoreline. The lagoon and channel were $3 \mathrm{~m}$

373 deep and connected to a beach face with a concave profile $z=A x^{2 / 3}$ [Dean, 1977; González

374 et al., 1999], where $x$ is the cross-shore coordinate, and $A$ was set to 0.15 . All simulations

375 were forced at the offshore boundary by waves comprised of a JONSWAP spectrum of

376 normally incident waves with peak period $T_{p}=14 \mathrm{~s}$ (the average observed during the

377 experiment at Garden Island), a peak enhancement factor of $\gamma_{\text {jonswap }}=3.3$ and a directional

378 spreading of $\sigma=25^{\circ}$. Simulations with the same wave height were forced by identical time

379 series. After a one-hour spin-up time, 2121 uniformly spaced drifters were seeded as passive

380 particles inside the reef-lagoon system and their tracks were simulated for three hours using

381 Lagrangian particle tracking.

The reef parameters (channel spacing and reef friction) and hydrodynamic forcing

383 (offshore wave height and along-shelf current) were varied independently according to Table

3843 , resulting in a total of 320 simulations. The choice of hydrodynamic parameters was

385 motivated by the field observations (see section 3.4) and the reef parameters were chosen

386 based on initial parameter tests and also varied to cover a range of typical fringing reef

387 dimensions with channel spacing from $300 \mathrm{~m}$ to $700 \mathrm{~m}$ [Falter et al., 2013] and roughness

388 values, which have been previously reported to range from $c_{f}=0.009$ to 0.027 [Rosman and

389 Hench, 2011].

Table 3. Parameters (see also Figure 6) and parameter values used in the sensitivity test.

Parameter values for the default case are highlighted in bold.

\begin{tabular}{|c|c|}
\hline Parameter & Values \\
\hline \multicolumn{2}{|l|}{ Variable } \\
\hline Channel spacing $\lambda$ & $300, \mathbf{4 0 0}, 500,600,700 \mathrm{~m}$ \\
\hline Reef friction $c_{f, R}$ & $0.003, \mathbf{0 . 0 1}, 0.03,0.1$ \\
\hline Significant offshore wave height $H_{m 0}$ & $1.0, \mathbf{1 . 5}, 2.0,2.5 \mathrm{~m}$ \\
\hline Alongshelf current & $\mathbf{0}, 0.05,0.10,0.15 \mathrm{~m} \mathrm{~s}^{-1}$ \\
\hline
\end{tabular}




\begin{tabular}{|l|l|}
\hline \multicolumn{2}{|l|}{ Constant } \\
\hline Reef length $L_{R}$ & $150 \mathrm{~m}$ \\
\hline Reef depth $h_{R}$ & $1.5 \mathrm{~m}$ \\
\hline Channel width $W_{C}$ & $100 \mathrm{~m}$ \\
\hline Forereef slope $m$ & $1: 40$ \\
\hline Lagoon depth $h_{\text {Lag }}$ & $3 \mathrm{~m}$ \\
\hline
\end{tabular}

390

To determine the exit and re-entrainment rates the modelled drifters were first allowed simulation. This time was sufficient for drifters to finish at least one circulation cycle even in large lagoons. This approach is similar to the time averaged values used by Castelle et al. [2014], Castelle and Coco [2013] and Reniers et al. [2009].

\subsection{Hindcast Model Results}

(RMSE), bias and the Willmott skill (WS) [Willmott et al., 1985], which are defined as:

$$
\begin{gathered}
R M S E=\sum_{i=1}^{N} \sqrt{\left|X_{\text {mod }}-X_{o b s}\right|^{2}} \\
\text { bias }=\sum_{i=1}^{N} X_{\text {mod }}-X_{o b s} \\
W S=1-\frac{\sum_{i=1}^{N}\left|X_{m o d}-X_{o b s}\right|^{2}}{\sum_{i=1}^{N}\left(\left|X_{\text {mod }}-\bar{X}_{o b s}\right|+\left|X_{o b s}-\bar{X}_{o b s}\right|\right)^{2}}
\end{gathered}
$$

401 where $X_{m o d}$ and $X_{o b s}$ are the modelled and observed values (here sea-swell wave height $H_{m 0}$,

$402 u_{\text {mean }}$ and $\left.v_{\text {mean }}\right)$, the overbar indicates time averaging of these values and $N$ is the number of 403 samples ( $N=64$, four simulations per day). 
At sites inside the lagoon (S7), offshore from the reef (R7) and on the reef platform

405

406

407

408

409

410

411

412

413

414

415

416

417

418

419

420

421

422

423

424

425

426

427

(R2), the wave heights were accurately predicted over the duration of the experiment (RMSE $=0.08-0.13 \mathrm{~m}$, bias $=-0.07-0.12 \mathrm{~m}$ and $\mathrm{WS}=0.82-0.92$, Table 2). However, in the channel at CS2 and CS4 the model overestimated wave heights consistently by $20 \%$. This may be due to visually observed bathymetric features inside the channel, which are smaller than the resolution of the LiDAR bathymetry $(\sim 5 \mathrm{~m})$, and thus not resolved in the model. Further, wave diffraction may play a role at this site, which is not in the model. The alongshore velocities in the channel at CS2 and CS4 were consistently overestimated by $\sim 0.1$ $\mathrm{m} \mathrm{s}^{-1}$ but followed the trends in the observations well. This resulted in a flow that was directed slightly more alongshore in the model, despite the total velocity magnitude being predicted well (not shown). Overall, the RMSE for the modelled velocities ranged between 0.05 and $0.13 \mathrm{~m} \mathrm{~s}^{-1}$, the bias between -0.11 and $0.12 \mathrm{~m} \mathrm{~s}^{-1}$ and the WS was between 0.78 and 0.95 (Table 2).

The model results were predominantly compared spatially to the observed drifter tracks as for the objectives of this study the spatial patterns were most important. The model produced a circulation cell to the north of the channel, which is in agreement with the observed drifter re-entrainment (Figure 3a, b). However, the modelled re-entrainment cell had a somewhat wider radius than in the field observations, which is most likely due to the combination of bathymetry and model resolution not being able to capture the very steep bed level gradient from the channel to the reef resulting in a more alongshore directed flow. The model also reproduced the southwesterly trajectory of flow exiting the southern channel (Figure 3c, d). Overall, the model was able to replicate the flow magnitudes, directions and patterns with reasonable accuracy and was able to qualitatively reproduce the observed flow patterns. 


\subsection{Effect of hydrodynamic and reef geometry parameters}

The primary goal of the numerical model was to identify the parameters and

430 mechanisms that control flow re-entrainment. For each simulation with varying reef geometry

431 and hydrodynamic forcing the exit rates $E_{1}$ and $E_{2}$ (Eq. (3) and (4), respectively) and re-

432 entrainment $b$ (Eq. (5)) were calculated. The mean offshore and onshore velocity across all

433 reef channels and reef structures, respectively, were determined at the cross-shore location

434 where the offshore current in the channel was maximum. This location was typically just

435 offshore from the channel exit.
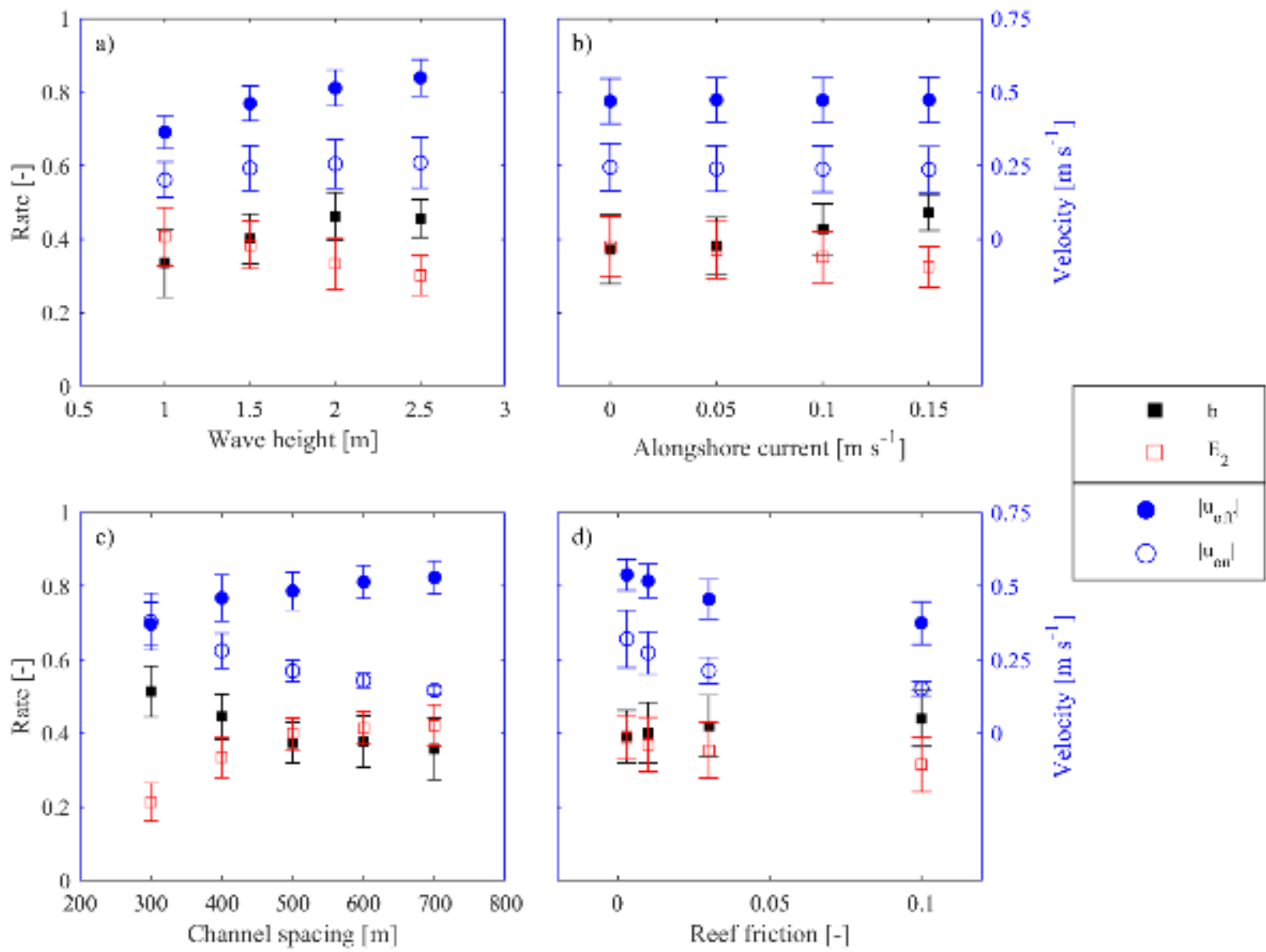

Figure 7. Re-entrainment $b$, exit rate $E_{2}$, average offshore velocity in the channel and average onshore velocity at the reef edge as functions of variations in a) wave height, b) alongshore current outside the reef, c) channel spacing and d) lagoon length. The circle marks the mean value of all simulations and the black bar indicates the range in which $50 \%$ of the simulation 
results fall within.

The drifter re-entrainment $b$ increased (exit rate $E_{2}$ decreased) with increasing wave height (Figure 7a) and increasing alongshore current outside the reef (Figure 7b). Large waves caused the maximum offshore flow velocity in the channel and the onshore flow velocity over the reef to increase (Figure 7a) while the alongshore velocity outside the reef had no impact on the cross-shore velocities (Figure 7b). With large channel spacing reentrainment $b$ decreased (exit rate $E_{2}$ increased) while the onshore velocities decreased and the offshore velocities increased (Figure 7c). Large bed roughness is a characteristic feature of many (or most) reefs that distinguishes these systems from analogous rip-channeled beach environments. Large reef friction equally reduced the onshore velocities over the reef and the offshore velocities in the channel. Drifters were thus neither more likely to exit offshore nor to return onshore over the reef and the re-entrainment of the drifters remained unchanged (Figure 7d).

\section{Discussion}

The dynamics of wave-driven flows in reef environments and ocean-reef exchange have been either studied in a Eulerian reference frame that quantifies the incoming water flux across the reef platform and the offshore flux exiting the reef channels [e.g. Hench et al., 2008; Hoeke et al., 2011; Lowe et al., 2009; Taebi et al., 2011] or by tracking simulated particles [Zhang et al., 2012]. These approaches have not allowed to identify the governing drivers of reef exchange processes. For estuarine exchange processes, the drivers of recirculation have been identified to be tidal residual currents and baroclinically driven currents [see Geyer and MacCready, 2014, for a review]. This study provides insight into the processes related to reef geometry and forcing conditions that control the proportion of water 
that recirculated in a reef system.

Field observations suggest that re-entrainment can vary substantially due to variations in hydrodynamic forcing conditions alone (incident wave heights and along-shelf currents). This is consistent with the numerical model that assessed the effect of a range of reef geometries along with a larger range of variable hydrodynamic conditions, so that reentrainment varied between $7 \%$ and $73 \%$. Importantly, these results demonstrate that the definition of the exit rate $E_{l}$ (Eq. (3)), which ignores the effect of re-entrainment and counts all drifters that flow seaward through the channel as exiting, was consistently higher over the range of tested parameters. This definition is analogous to flushing time estimates commonly used with Eulerian velocity measurements obtained using fixed (moored) instruments [e.g. Taebi et al., 2011]. Our results suggest that flushing time estimates purely based on the offshore velocity are not always representative because they discount the effect of flow reentrainment. In the following, we investigate the effect of a number of hydrodynamic and geometric parameters on reef re-entrainment to determine the conditions and environments in which flow re-entrainment is an important process to consider.

\subsection{Influence of hydrodynamic and reef geometry parameters on flow dynamics}

To further investigate how the physical mechanisms responsible for re-entrainment are controlled by reef geometry parameters and hydrodynamic forcing conditions, we first assessed the momentum balances (Appendix A) across the reef-lagoon system for the default simulation that was forced with $1.5 \mathrm{~m}$ waves. The channels were spaced $400 \mathrm{~m}$ apart and no alongshore current was imposed outside the reef (Table 3$)$. In this case, $71 \%\left(E_{1}\right)$ of all seeded drifters floated offshore through the channel and $43 \%\left(E_{2}\right)$ remained outside of the reef-lagoon system. Of the drifters that floated offshore $40 \%(b)$ were re-entrained back into the reef system. The wave forcing induced by wave breaking on the forereef and the reef 
483

484

485

486

487

488

489

490

491

492

platform (Figure 8a) was balanced mostly by cross-shore pressure gradients (Figure 8b, see also, e.g. Symonds et al., 1995; Taebi et al., 2012). The net forcing, which we refer to as the sum of the offshore directed pressure gradient and onshore directed wave forcing, is directed onshore over the reef platform (Figure 8c), where it drives the cross-reef current that contributes to a relevant bottom shear stress over shallow and rough reefs (Figure 8e). Near the channels, the net forcing is balanced by advection (Figure $8 \mathrm{~d}$ ) and generates counterrotating eddies (Figure 8f) that, together with the onshore flow over the reef, were responsible for re-entrainment (see also Figure 5). The following sections assess how this momentum balance changes, particularly the strength of the net forcing term, when hydrodynamic forcing or reef geometry are altered.
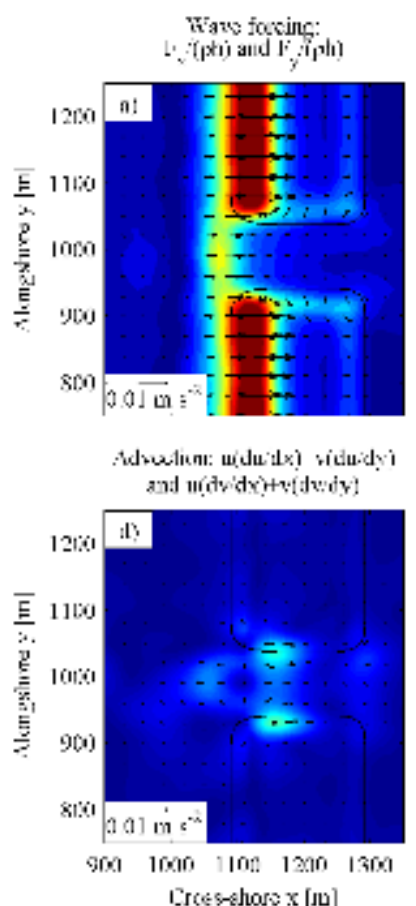

493

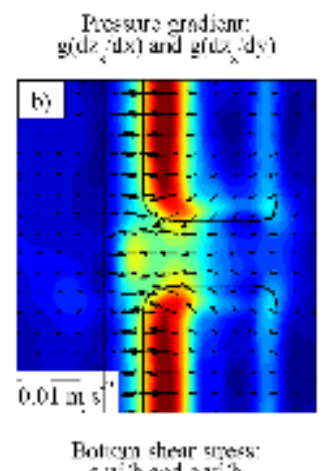

cath and $2 y^{2}$

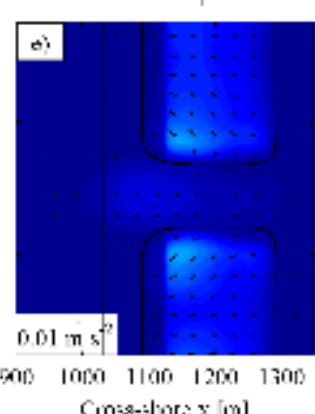

CLo:8-:bor: $x$ [in]
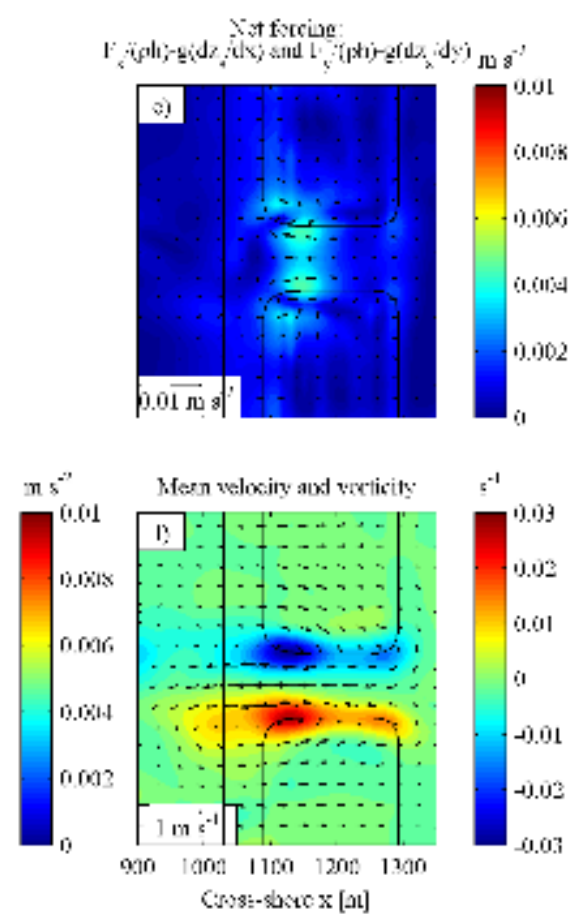

494 Figure 8. Simulated magnitude and direction of the momentum terms (cross- and alongshore, 495 see Eq. A1-2) for the default case. From top left to bottom right, the contributions from: a) 496 wave forcing, b) pressure gradient, c) sum of wave forcing and pressure gradient, d) non497 linear advection, e) bottom shear stress and f) mean velocity with Stokes drift (vectors) and 498 vorticity (colors). Viscosity terms were negligible and are not shown. Black contour lines 499 indicate the $-2.5 \mathrm{~m}$ and $-1 \mathrm{~m}$ isobaths. For clarity only every third vector is shown in cross- 
and alongshore direction.

$501 \quad 5.1 .1$ Wave height

In both the field observations and the numerical model, the re-entrainment increased

503 with larger offshore wave heights. Larger waves strengthen the net forcing responsible for the

504 wave-driven flows (i.e., the difference between the wave forcing and pressure gradient) just

505 offshore from the reef $(x=1050 \mathrm{~m}$, Figure $9 \mathrm{a})$ and on the parts of the reef near the channel

506 from where the offshore flow is primarily fed [Svendsen et al., 2000]. This net forcing drives

507 a stronger onshore flow just outside the reef and a stronger offshore flow in the channel

508 (Figure 7a), which also enhances the strength of the channel vortices (Figure 9b) that

509 ultimately re-entrain water back into the reef-lagoon system. Therefore, although larger

510 waves drive a stronger seaward flow out the channel (Figure 7a), which was also observed at

511 the field site $\left(r^{2}=0.89\right.$ between offshore waves and seaward flow velocities $)$ and other reef

512 sites [e.g. Lowe et al., 2009], larger waves also enhance flow re-entrainment.
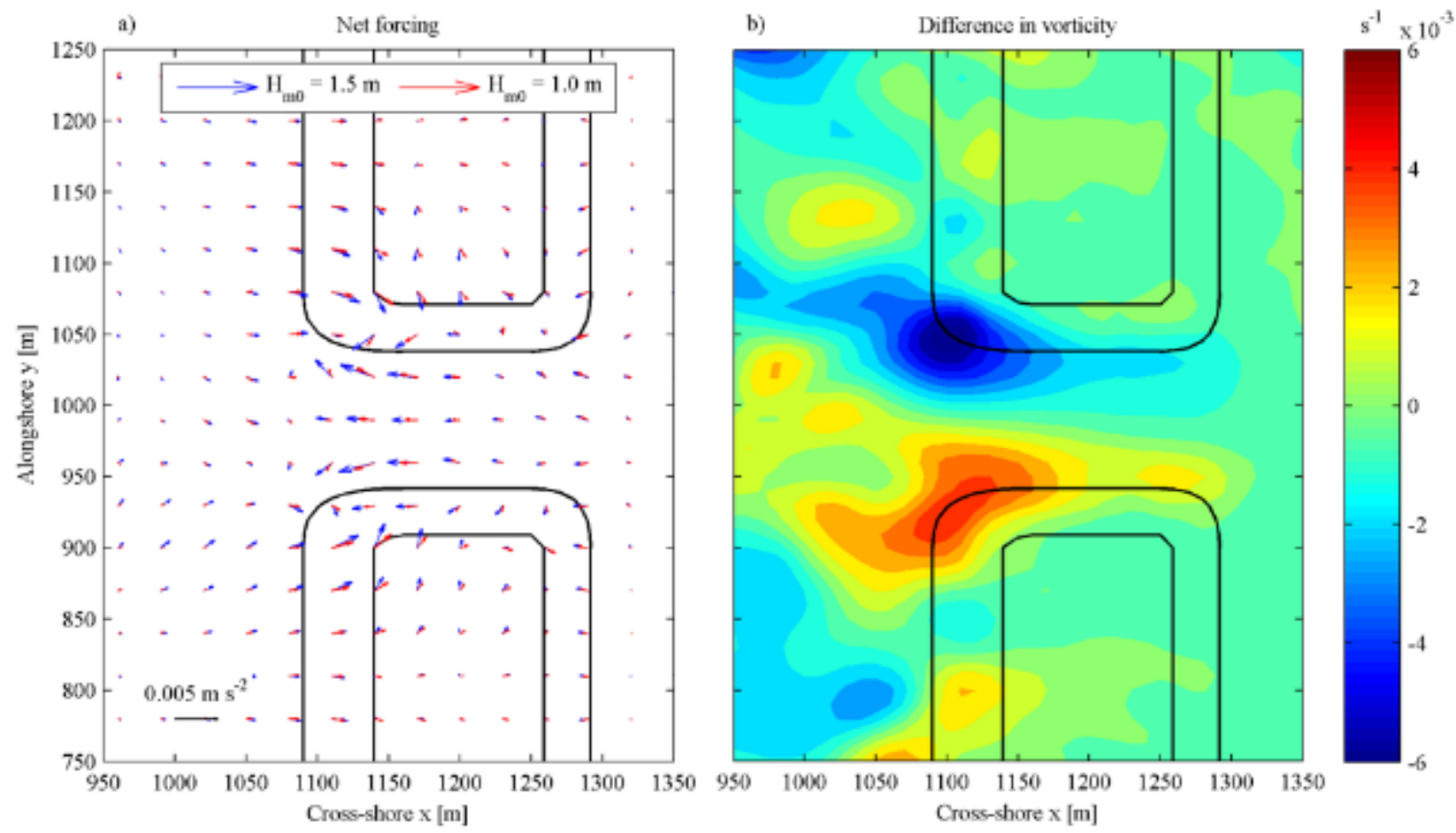

513 Figure 9. a) Modeled net forcing as the sum of the pressure gradient and wave forcing for a 
514 simulation during small waves $\left(H_{m 0}=1.0 \mathrm{~m}, b=24 \%\right.$, red arrows) and the default case

$515\left(H_{m 0}=1.5 \mathrm{~m}, b=38 \%\right.$, blue arrows). b) Difference in vertical vorticity between the two

516 simulations.

The increase of drifter re-entrainment with increasing wave height causes the exit rate

$519 E_{2}$ to decrease, which is consistent with field observations and modeling studies on rip-

520 channeled beaches [Castelle et al., 2014; Scott et al., 2014]. These studies have linked the decrease in exit rate to: (1) increased onshore flow over the sand bars, which transports drifters back towards shore [Scott et al., 2014], and to (2) wider surf zones [Castelle et al., 2014; Reniers et al., 2009]. However, the surf zone width depends largely on the forereef slope and varies less on steep forereefs. Here, we attribute the increased flow-re-entrainment to the stronger onshore mass flux over the reef. An increase of re-entrainment with larger waves implies that large storm waves may be increasingly less efficient in flushing costal reef systems.

\subsubsection{Alongshore current}

In the presence of an inner-shelf alongshore current, the offshore current in the

530 channel is redirected towards the downdrift direction (Figure 10a). The cross-shore current

531 locally blocks the alongshore current resulting in a local increase in the water level updrift of the channel and conversely a local decrease in the water level downdrift of the channel (Figure 10). The modified pressure gradient, and thus the net forcing, are redirected towards

534 the downstream reef (Figure 10). This allows water to be transported towards the reef and

535 then back shoreward by the wave-driven cross-reef flow such that the re-entrainment $b$

536 increases and the exit rate $E_{2}$ decreases. This is consistent with the field observations at 537 Garden Island where drifters returned via the reef to the north of the channel when the 
538

539

540

541

542

alongshore current outside the reef was directed northward. Herdman [2012] observed similar dynamics at a large-scale coral reef where it was found that more drifters returned over a downdrift reef in the presence of an increasing alongshore current. Similar observations have been made on rip-channeled beaches where drifter re-entrainment increased in the presence of alongshore currents associated with tidal flows [Winter et al., 2014].
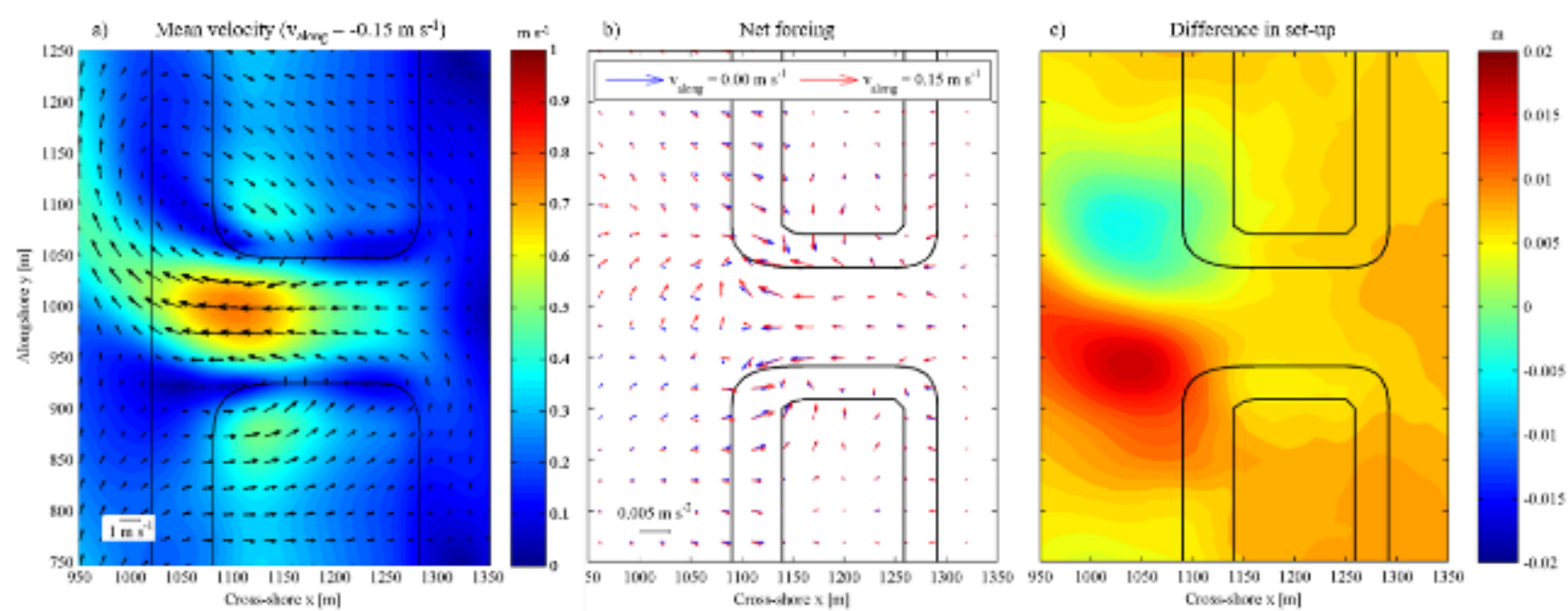

543 Figure 10. a) Mean velocity field for a simulation with a strong alongshore current

$\left.544\left(v_{0}=0.15 \mathrm{~ms}^{-1}\right) . \mathrm{b}\right)$ Net forcing as the sum of the pressure gradient and wave forcing for a

545 simulation with strong alongshore current $\left(v_{0}=0.15 \mathrm{~ms}^{-1}, b=62 \%\right.$, red arrows) compared to

546 the default case (without alongshore current, $b=38 \%$, blue arrows). c) Setup difference

547 between those simulations (red colors indicate greater setup in the simulation with strong

548 alongshore current).

\subsubsection{Channel spacing}

550 As the channel spacing increases, the ratio of channel width to alongshore reef width

551 decreases. To balance the volume of water flowing across the reef into the lagoon with the

552 volume of water flowing out through the channel, the seaward velocity in the channel increases for larger channel spacing while the maximum onshore velocity over the reef 
554 decreases (Figure 7c). Hence, water is advected further offshore rather than back towards the reef. Drifter retention also decreases with increasing channel spacing on rip-channeled beaches [Castelle et al., 2014]. However, this study shows that this effect weakens with larger channel spacing until a limit is reached where re-entrainment becomes approximately constant (i.e. in larger-scale reef systems, re-entrainment becomes insensitive to the channel spacing). Within the parameter space that we tested, this limit was $\sim 500 \mathrm{~m}$. Our results are consistent with observations of less re-entrainment in large reef systems at Moorea, where reef channels are 4 to $5 \mathrm{~km}$ apart and re-entrainment was less than 50\% [Herdman, 2012]. Thus, small-scale reef systems appear to promote large re-entrainment rates. hydrodynamic parameters, we define a re-entrainment predictor variable $R$ as:

$$
R=\frac{H_{m 0}}{h_{\text {reef }}} \frac{W_{c}}{\lambda}
$$

566 Here the ratio of the offshore significant wave height to the water depth over the reef

$567\left(H_{m 0} / h_{\text {reef }}\right)$ provides an indication of the intensity of wave dissipation on the reef; whereas

568 the ratio of the channel width to the channel spacing $\left(W_{c} / \lambda\right)$ provides a measure for the

569 relative cross-sectional areas available for onshore and offshore mass transport. Both of these

570 ratios affect the balance between onshore flow velocity over the reef and offshore flow

571 velocity inside the channel. Stronger onshore flow over the reef favors drifter-re-entrainment

572 and stronger offshore flow transports drifters further offshore from where they are less likely

573 to be re-entrained. The alongshore current is considered separately because the re-

574 entrainment mechanism is fundamentally different (see section 5.1). An alongshore current

575 does not affect the cross-shore flow velocities but enhances flow re-entrainment because it 
576 transports drifters towards an area of onshore flow.

We found that the exit rate $E_{2}$ decreases with $R\left(r^{2}=0.70\right.$ in the absence of alongshore currents) following a negative reciprocal function while re-entrainment $(b)$ increases with increasing values of $R$ and plateaus with high values of $R$ following a positive reciprocal

580 function. In the absence of an alongshore current, $b$ and the reciprocal of parameter $R$ are 581 correlated $\left(r^{2}=0.73\right)$. With increasing alongshore current outside the reef the correlation

582 between $R$ and $b$ reduces, i.e. when the current outside the reef is $0.15 \mathrm{~m} \mathrm{~s}^{-1}$, the correlation coefficient drops to $r^{2}=0.25$ and re-entrainment is consistently higher across all values of $R$

584 (Figure 11). The alongshore current outside the reef then dominates the re-entrainment

585 process. For large values of $R(>0.4)$, re-entrainment is less sensitive to the alongshore

586 current outside the reef and the re-entrainment rates converge for all tested alongshore current

587 magnitudes. To summarize, $R$ and the alongshore current both increase re-entrainment, but 588 when the alongshore current is strong it reduces the sensitivity to variations of $R$ and vice versa. 

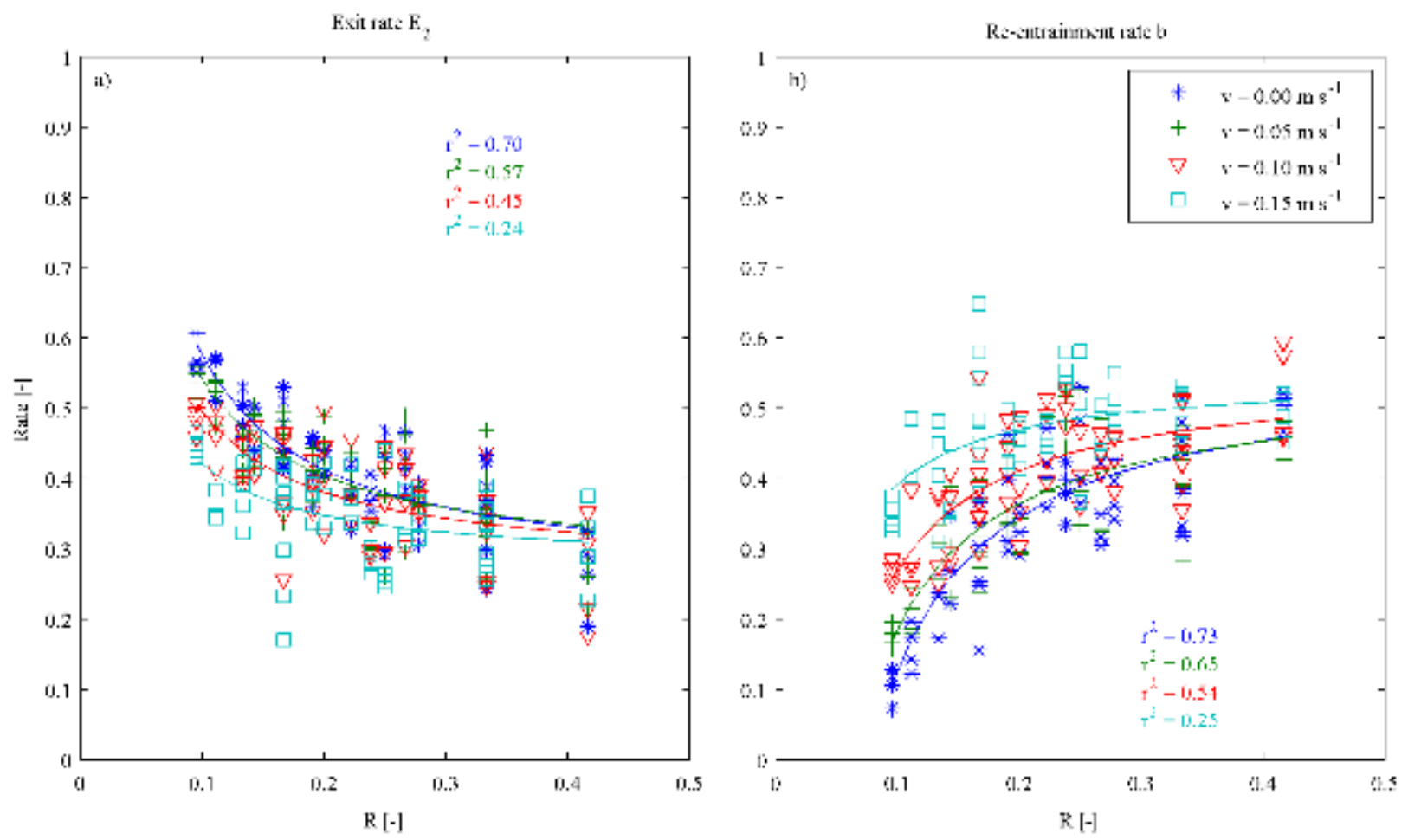

Figure 11. Exit rate $E_{2}$ (a) and re-entrainment $b$ (b) versus the re-entrainment prediction parameter $R$ for all simulations. The different marker colors denote variable alongshore currents outside the reef.

To demonstrate the implications of the large variability in re-entrainment $(b)$ for reef

592 flushing times, we calculated the flushing time with re-entrainment (Eq. (2)) and without reentrainment (Eq. (1)). In many simulations, the inclusion of $b$ in the estimate substantially

594 increased the flushing time compared to an estimate without re-entrainment: for $58 \%$ of the

595 simulations the flushing time increased by more than a factor of 1.5 and in $17 \%$ of the

596 simulations by more than two. The largest increase (greater than three times) was observed

597 for the simulations with large $R$ (a combination of short channel spacing $\lambda=300 \mathrm{~m}$ and wave

598 heights of $H_{m 0}>2 \mathrm{~m}$ ) and strong alongshore currents. In contrast, there was little difference

599 between the two flushing times in simulations with small $R$ (channel spacing $\lambda>500 \mathrm{~m}$ and

$\left.600 \quad H_{m 0}=1 \mathrm{~m}\right)$ and no alongshore current. 


\section{Conclusions}

This study examined the processes responsible for re-entrainment in wave-dominated reef systems. Drifter observations in a wave-dominated rocky limestone reef in southwestern Australia illustrated two distinct flow patterns of either complete drifter ejection or drifter reentrainment. These observations motivated an idealized numerical study that investigated the effect of reef channel spacing and reef roughness along with offshore wave height and alongshore currents on flow re-entrainment. The model demonstrated that large waves and strong alongshore currents outside the reef enhance flow re-entrainment. The model results further showed that large reef channel spacing reduces flow re-entrainment, while the reef roughness had no effect. A single re-entrainment prediction parameter $R$ is proposed, which

611 incorporates the effect of wave forcing and reef geometry. For large values of $R$ (i.e. large

612 offshore wave height and small channel spacing) and strong alongshore currents outside the

613 reef flow re-entrainment is important to consider in reef flushing time estimates. Large wave

614 heights can dominate the re-entrainment mechanism and reduce the positive effect of an

615 alongshore current outside the reef and vice versa.

The present study demonstrates that re-entrainment rates can be large and highly

617 variable among reefs, and thus should be included when assessing flushing times and material exchange of reef systems with the surrounding ocean. High re-entrainment rates may limit the ability of a reef to exchange material with both the surrounding ocean and other reef systems, and thus further emphasizes the need to accurately quantify flow re-entrainment to make

621 robust estimates of, for example, larval dispersal, reef connectivity [Cowen et al., 2000; Teske 622 et al., 2016] and reef water quality [Falter et al., 2013; Lowe and Falter, 2015]. Flow reentrainment is generally important for reefs that are frequently intercepted by channels and reefs that are exposed to large waves and strong alongshore currents outside the reef. 


\section{Acknowledgements}

We are grateful to Andrew Pomeroy, Mike Cuttler, Anton Kuret, Laura Segura and

627 Mark Buckley for assistance with the instrument deployment and recovery. Funding for this 628 project was provided by an ARC Future Fellowship (FT110100201) and ARC Discovery 629 Project (DP140102026) to RJL. This work was undertaken by GW as part of a PhD at The 630 University of Western Australia and was funded by an International Postgraduate Research 631 Scholarship, an Australian Postgraduate Award and an EA and CH Jenkins scholarship. GW 632 also acknowledges a Sue Baker Convocation Travel Award, which allowed her to visit the 633 University of Bordeaux, where a large part of this manuscript was developed. BC was 634 financially supported by projects DECA (INSU/EC2CO-DRIL) and CHIPO (grant number 635 ANR-14-ASTR-0004-01) supported by the Agence Nationale de la Recherche (ANR).

636 Funding for RM was provided by the "Hydro- and morphodynamics during extreme events" 637 research program of Deltares. The numerical modeling work was supported by resources 638 provided by The Pawsey Supercomputing Centre with funding from the Australian 639 Government and the Government of Western Australia. The data are available under 640 http://doi.org/10.5281/zenodo.1292064.

\section{Appendix A. Momentum equations}

642 Output from the idealized XBeach simulations was used to assess the relative

643 importance of the terms of the steady $(d / d t=0)$ depth and time (wave) averaged momentum 644 balances in cross (x)- and alongshore (y) direction including the wave (radiation stress)

645 forcing, $F_{x}$ and $F_{y}$, as source term and pressure gradients, advection, turbulent mixing, and 646 bottom shear stress, as sink terms: 


$$
\begin{gathered}
\frac{F_{x}}{\rho}-g(\eta+h) \frac{\partial \eta}{\partial x}-(\eta+h)\left(u \frac{\partial u}{\partial x}+v \frac{\partial u}{\partial y}\right)-v_{H}(\eta+h)\left(\frac{\partial^{2} u}{\partial x^{2}}+\frac{\partial^{2} u}{\partial y^{2}}\right) \\
-\frac{\tau_{x}^{b}}{\rho}=0 \\
\frac{F_{y}}{\rho}-g(\eta+h) \frac{\partial \eta}{\partial y}-(\eta+h)\left(u \frac{\partial v}{\partial x}+v \frac{\partial v}{\partial y}\right)-v_{H}(\eta+h)\left(\frac{\partial^{2} v}{\partial x^{2}}+\frac{\partial^{2} v}{\partial y^{2}}\right) \\
-\frac{\tau_{y}^{b}}{\rho}=0
\end{gathered}
$$

647 where $\rho$ is the water density, $\eta$ is setup, $h$ the still water depth, $u$ and $v$ are the cross- and 648 alongshore velocities, $v_{H}$ the horizontal viscosity and $\tau_{x}^{b}$ and $\tau_{y}^{b}$ are the bottom shear stresses 649 in cross- and alongshore direction. The wave forcing is calculated from the radiation stress 650 gradients $S_{i j}$ as follows:

$$
\begin{aligned}
& F_{x}=-\left(\frac{\partial\left(S_{x x}+S_{x x, \text { roller }}\right)}{\partial x}+\frac{\partial\left(S_{x y}+S_{x y, \text { roller }}\right)}{\partial y}\right) \\
& F_{y}=-\left(\frac{\partial\left(S_{y x}+S_{y x, \text { roller }}\right)}{\partial x}+\frac{\partial\left(S_{y y}+S_{y y, \text { roller }}\right)}{\partial y}\right)
\end{aligned}
$$

651 
652

653

654

655

656

657

658

659

660

661

662

663

664

665

666

667

668

669

670

671

672

673

674

675

676

\section{References}

Austin, M. J., T. M. Scott, J. W. Brown, J. A. Brown, J. H. MacMahan, G. Masselink, and P. Russell (2010), Temporal observations of rip current circulation on a macro-tidal beach, Continental Shelf Research, 30, 1149-1165, doi:10.1016/j.csr.2010.03.005.

Barnard, P. L., J. E. Hansen, and L. H. Erikson (2012), Synthesis study of an erosion hot spot, Ocean Beach, California, Journal of Coastal Research, 28(4), 903-922, doi:10.2112/JCOASTRES-D-11-00212.1.

Black, K. P., S. L. Gay, and J. C. Andrews (1990), Residence times of neutrally-buoyant matter such as larvae, sewage or nutrients on coral reefs, Coral Reefs, 9(3), 105-114, doi:10.1007/bf00258221.

Bosserelle, C., Pattiaratchi, C., \& Haigh, I. (2012), Inter-annual variability and longer-term changes in the wave climate of Western Australia between 1970 and 2009. Ocean Dynamics, 62(1), 63-76. https://doi.org/10.1007/s10236-011-0487-3

Brown, J. A., J. H. MacMahan, A. J. H. M. Reniers, and E. B. Thornton (2015), Field Observations of Surf Zone-Inner Shelf Exchange on a Rip-Channeled Beach, Journal of Physical Oceanography, 45(9), 2339-2355, doi:10.1175/JPO-D-14-0118.1.

Buckley, M. L., R. J. Lowe, J. E. Hansen, and A. R. Van Dongeren (2016), Wave Setup over a Fringing Reef with Large Bottom Roughness, Journal of Physical Oceanography, 46(8), 2317-2333, doi:10.1175/JPO-D-15-0148.1.

Bureau of Meterology Commonwealth of Australia (2014), Climate statistics for Australian locations, edited by BOM, Bureau of Meterology, Commonwealth of Australia, Melbourne.

Castelle, B., and G. Coco (2013), Surf zone flushing on embayed beaches, Geophysical Research Letters, 40(10), 2206-2210, doi:10.1002/grl.50485.

Castelle, B., A. J. H. M. Reniers, and J. H. MacMahan (2014), Bathymetric control of surf 
677

678

679

680

681

682

683

684

685

686

687

688

689

690

691

692

693

694

695

696

697

698

699

700

701

zone retention on a rip-channelled beach, Ocean Dynamics, 64(8), 1221-1231, doi:10.1007/s10236-014-0747-0.

Castelle, B., T. Scott, R. W. Brander, and R. J. McCarroll (2016), Rip current types, circulation and hazard, Earth-Science Reviews, 163, 1-21, doi:10.1016/j.earscirev.2016.09.008.

Coronado, C., J. Candela, R. Iglesias-Prieto, J. Sheinbaum, M. López, and F. J. OcampoTorres (2007), On the circulation in the Puerto Morelos fringing reef lagoon, Coral Reefs, 26(1), 149-163, doi:10.1007/s00338-006-0175-9.

Cowen, R. K., K. M. M. Lwiza, S. Sponaugle, C. B. Paris, and D. B. Olson (2000), Connectivity of Marine Populations: Open or Closed?, Science, 287(5454), 857, doi:10.1126/science.287.5454.857

Dalrymple, R. A., J. H. MacMahan, A. J. H. M. Reniers, and V. Nelko (2011), Rip Currents, Annual Review of Fluid Mechanics, 43(1), 551-581, doi:10.1146/annurev-fluid122109-160733.

Dean, R. G. (1977), Equilibrium beach profiles: US Atlantic and Gulf coasts. Rep., University of Delaware.

Department of Transport Western Australia (2009), Two Rocks to Cape Naturaliste Bathymetry and Seabed LiDAR Survey, edited by DoT, Department of Transport, Western Australia, Perth.

Falter, J. L., M. J. Atkinson, and M. A. Merrifield (2004), Mass-transfer limitation of nutrient uptake by a wave-dominated reef flat community, Limnology and Oceanography, 49(5), 1820-1831, doi:10.4319/1o.2004.49.5.1820.

Falter, J. L., R. J. Lowe, Z. Zhang, and M. McCulloch (2013), Physical and Biological Controls on the Carbonate Chemistry of Coral Reef Waters: Effects of Metabolism, Wave Forcing, Sea Level, and Geomorphology, PLoS ONE, 8(1), e53303, 
702

703

704

705

706

707

708

709

710

711

712

713

714

715

716

717

718

719

720

721

722

723

724

725

726

doi:10.1371/journal.pone.0053303.

Feddersen, F., R. T. Guza, S. Elgar, and T. H. C. Herbers (1998), Alongshore momentum balances in the nearshore, Journal of Geophysical Research: Oceans, 103(C8), 15667-15676, doi:10.1029/98jc01270.

Feddersen, F., R. T. Guza, S. Elgar, and T. H. C. Herbers (2000), Velocity moments in alongshore bottom stress parameterizations, Journal of Geophysical Research: Oceans, 105(C4), 8673-8686, doi:10.1029/2000jc900022.

Fischer, H. B., J. E. List, C. R. Koh, J. Imberger, and N. H. Brooks (1979), Mixing in Inland and Coastal Waters, Academic Press, New York.

Gersbach, G. H., C. B. Pattiaratchi, G. N. Ivey, and G. R. Cresswell (1999), Upwelling on the south-west coast of Australia—source of the Capes Current?, Continental Shelf Research, 19(3), 363-400, doi:10.1016/S0278-4343(98)00088-0.

Geyer, W. R., \& MacCready, P. (2014), The Estuarine Circulation. Annual Review of Fluid Mechanics, 46(1), 175-197, doi:10.1146/annurev-fluid-010313-141302

González, M., R. Medina, and M. A. Losada (1999), Equilibrium beach profile model for perched beaches, Coastal Engineering, 36(4), 343-357, doi:10.1016/S03783839(99)00018-6.

Hally-Rosendahl, K., F. Feddersen, and R. T. Guza (2014), Cross-shore tracer exchange between the surfzone and inner-shelf, Journal of Geophysical Research: Oceans, 119(7), 4367-4388, doi:10.1002/2013JC009722.

Hench, J., L., J. J. Leichter, and S. G. Monismith (2008), Episodic circulation and exchange in a wave-driven coral reef and lagoon system, Limnol. Oceanogr., 53(6), 2681-2694, doi:10.4319/lo.2008.53.6.2681.

Herdman, L. M. M. (2012), Circulation, Residence Time and Retention in a Tropical Coral Reef, Stanford University. 
727

728

729

730

731

732

733

734

735

736

737

738

739

740

741

742

743

744

745

746

747

748

749

750

751

Herdman, L. M. M., J. L. Hench, and S. G. Monismith (2015), Heat balances and thermally driven lagoon-ocean exchanges on a tropical coral reef system (Moorea, French Polynesia), Journal of Geophysical Research: Oceans, 120, 1233-1252, doi:10.1002/2014JC010145.

Hoeke, R., C. D. Storlazzi, and P. Ridd (2011), Hydrodynamics of a bathymetrically complex fringing coral reef embayment: Wave climate, in situ observations, and wave prediction, Journal of Geophysical Research: Oceans, 116(C4), C04018, doi:10.1029/2010JC006170.

Kench, S. P. (1998), Physical processes in an Indian Ocean atoll, Coral Reefs, 17(2), 155168, doi:10.1007/s003380050110.

Kraines, B. S., A. Suzuki, T. Yanagi, M. Isobe, X. Guo, and H. Komiyama (1999), Rapid water exchange between the lagoon and the open ocean at Majuro Atoll due to wind, waves and tide, Journal of Geophysical Research, 104(C7), 15635-15653, doi:10.1029/1999JC900065.

Large, W. G., and S. Pond (1981), Open Ocean Momentum Flux Measurements in Moderate to Strong Winds, Journal of Physical Oceanography, 11(3), 324-336, doi:10.1175/1520-0485(1981)011<0324:OOMFMI>2.0.CO;2.

Longuet-Higgins, M. S. (1962), Radiation stress and mass transport in gravity waves, with application to 'surf beats', Journal of Fluid Mechanics, 13(04), 481- 504, doi:10.1017/S0022112062000877.

Lowe, R. J., and J. L. Falter (2015), Oceanic Forcing of Coral Reefs, Annual Review of Marine Science, 7(1), 43-66, doi:10.1146/annurev-marine-010814-015834.

Lowe, R. J., J. L. Falter, S. G. Monismith, and M. J. Atkinson (2009), Wave-Driven Circulation of a Coastal Reef-Lagoon System, Journal of Physical Oceanography, 39(4), 873-893, doi:10.1175/2008JPO3958.1. 
752

753

754

755

756

757

758

759

760

761

762

763

764

765

766

767

768

769

770

771

772

773

774

775

776

Lowe, R. J., C. Hart, and C. B. Pattiaratchi (2010), Morphological constraints to wave-driven circulation in coastal reef-lagoon systems: A numerical study, Journal of Geophysical Research: Oceans, 115(C9), C09021, doi:10.1029/2009JC005753.

Lugo-Fernández, A., K. J. P. Deslarzes, J. M. Price, G. S. Boland, and M. V. Morin (2001), Inferring probable dispersal of Flower Garden Banks Coral Larvae (Gulf of Mexico) using observed and simulated drifter trajectories, Continental Shelf Research, 21(1), 47-67, doi:10.1016/S0278-4343(00)00072-8.

MacMahan, J. H. (2001), Hydrographic surveying from a personal watercraft, Journal of Surveying Engineering, 127(1), 12-24, doi:10.1061/(ASCE)07339453(2001)127:1(12)\#sthash.boohLR0J.dpuf.

MacMahan, J. H., et al. (2010a), Mean Lagrangian flow behavior on an open coast ripchanneled beach: A new perspective, Marine Geology, 268(1-4), 1-15, doi:10.1016/j.margeo.2009.09.011.

MacMahan, J. H., A. J. H. M. Reniers, and E. B. Thornton (2010b), Vortical surf zone velocity fluctuations with 0(10) min period, Journal of Geophysical Research: Oceans, 115(C6), C06007, doi:10.1029/2009JC005383.

McCarroll, R. J., R. W. Brander, T. Scott, and B. Castelle (2018), Bathymetric controls on rotational surfzone currents, Journal of Geophysical Research: Earth Surface, 123(6), 1295-1316.

McCarroll, R. J., R. W. Brander, I. L. Turner, H. E. Power, and T. R. Mortlock (2014), Lagrangian observations of circulation on an embayed beach with headland rip currents, Marine Geology, 355, 173-188, doi:10.1016/j.margeo.2014.05.020.

Monismith, S. G. (2013), Flow through a rough, shallow reef, Coral Reefs, 33(1), 99-104, doi:10.1007/s00338-013-1107-0.

Monsen, N. E., J. E. Cloern, L. V. Lucas, and S. G. Monismith (2002), A comment on the use 
of flushing time, residence time, and age as transport time scales, Limnology and Oceanography, 47(5), 1545-1553, doi:10.4319/1o.2002.47.5.1545.

Morgan, S. G., A. L. Shanks, A. G. Fujimura, A. J. H. M. Reniers, J. MacMahan, C. D. Griesemer, M. Jarvis, and J. Brown (2016), Surfzone hydrodynamics as a key determinant of spatial variation in rocky intertidal communities, Proceedings of the Royal Society B: Biological Sciences, 283(1840), doi:10.1098/rspb.2016.1017.

Reidenbach, M. A., S. G. Monismith, J. R. Koseff, G. Yahel, and A. Genin (2006), Boundary layer turbulence and flow structure over a fringing coral reef, Limnology and Oceanography, 51(5), 1956-1968, doi:10.4319/lo.2006.51.5.1956.

Reniers, A. J. H. M., J. H. MacMahan, E. B. Thornton, T. P. Stanton, M. Henriquez, J. W. Brown, J. A. Brown, and E. Gallagher (2009), Surf zone surface retention on a ripchanneled beach, Journal of Geophysical Research, 114(C10), C10010, doi:10.1029/2008jc005153.

Roelvink, J. A. (1993), Dissipation in random wave groups incident on a beach, Coastal Engineering, 19(1-2), 127-150, doi:10.1016/0378-3839(93)90021-Y.

Roelvink, J. A., A. J. H. M. Reniers, A. R. van Dongeren, J. S. M. van Thiel de Vries, R. T. McCall, and J. Lescinski (2009), Modelling storm impacts on beaches, dunes and barrier islands, Coastal Engineering, 56(11-12), 1133-1152, doi:10.1016/j.coastaleng.2009.08.006.

Rosman, J. H., and J. L. Hench (2011), A framework for understanding drag parameterizations for coral reefs, Journal of Geophysical Research: Oceans, 116(C8), C08025, doi:10.1029/2010JC006892.

Ruessink, B. G., J. R. Miles, F. Feddersen, R. T. Guza, and S. Elgar (2001), Modeling the alongshore current on barred beaches, Journal of Geophysical Research, 106, 2245122464, doi:10.1029/2000JC000766. 
802 Ruiz-Montoya, L., and R. J. Lowe (2014), Summer circulation dynamics within the Perth

803

804

805

806

807

808

809

810

811

812

813

814

815

816

817

818

819

820

821

822

823

824

825

826 coastal waters of southwestern Australia, Continental Shelf Research, 77(0), 81-95, doi:10.1016/j.csr.2014.01.022.

Sanford, L. P., W. C. Boicourt, and S. R. Rives (1992), Model for Estimating Tidal Flushing of Small Embayments, Journal of Waterway, Port, Coastal, and Ocean Engineering, 118(6), 635-654, doi:10.1061/(ASCE)0733-950X(1992)118:6(635).

Schmidt, W. E., B. T. Woodward, K. S. Millikan, R. T. Guza, B. Raubenheimer, and S. Elgar (2003), A GPS-tracked surf zone drifter, Journal of Atmospheric and Oceanic Technology, 20 (Compendex), 1069-1075, doi:10.1175/1460.1.

Scott, T., G. Masselink, M. J. Austin, and P. Russell (2014), Controls on macrotidal rip current circulation and hazard, Geomorphology, 214(0), 198-215, doi:10.1016/j.geomorph.2014.02.005.

Smagorinsky, J. (1963), General circulation experiments with the primitive equations, Monthly Weather Review, 91(3), 99-164, doi:10.1175/15200493(1963)091<0099: gcewtp>2.3.co;2.

Spydell, M. S. (2016), The Suppression of Surfzone Cross-shore Mixing by Alongshore Currents, Geophysical Research Letters, 43, doi:10.1002/2016GL070626.

Spydell, M. S., F. Feddersen, R. T. Guza, and W. E. Schmidt (2007), Observing surf-zone dispersion with drifters, Journal of Physical Oceanography, 37 (Compendex), 29202939, doi:10.1175/2007JPO3580.1.

Storlazzi, C. D., A. S. Ogston, M. H. Bothner, M. E. Field, and M. K. Presto (2004), Waveand tidally-driven flow and sediment flux across a fringing coral reef: Southern Molokai, Hawaii, Continental Shelf Research, 24(12), 1397-1419, doi:10.1016/j.csr.2004.02.010.

Svendsen, I. A., K. A. Haas, and Q. Zhao (2000), Analysis of Rip Current Systems, in 29th 
827

828

829

830

831

832

833

834

835

836

837

838

839

840

841

842

843

844

845

846

847

848

849

850

851

International Conference on Coastal Engineering, edited by B. L. Edge, pp. 11271140, American Society of Civil Engineers, Sydney.

Symonds, G., K. P. Black, and I. R. Young (1995), Wave-driven flow over shallow reefs, Journal of Geophysical Research: Oceans, 100(C2), 2639-2648, doi:10.1029/94JC02736.

Symonds, G., D. A. Huntley, and A. J. Bowen (1982), Two-dimensional surf beat: Long wave generation by a time-varying breakpoint, Journal of Geophysical Research, 87(C1), 492-498, doi:10.1029/JC087iC01p00492.

Taebi, S., R. J. Lowe, C. B. Pattiaratchi, G. N. Ivey, and G. Symonds (2012), A numerical study of the dynamics of the wave-driven circulation within a fringing reef system, Ocean Dynamics, 62(4), 585-602, doi:10.1007/s10236-011-0514-4.

Taebi, S., R. J. Lowe, C. B. Pattiaratchi, G. N. Ivey, G. Symonds, and R. Brinkman (2011), Nearshore circulation in a tropical fringing reef system, Journal of Geophysical Research: Oceans, 116(C2), 2156-2202, doi:10.1029/2010JC006439.

Tartinville, B., E. Deleersnijder, and J. Rancher (1997), The water residence time in the Mururoa atoll lagoon: sensitivity analysis of a three-dimensional model, Coral Reefs, 16(3), 193-203, doi:10.1007/s003380050074.

Teske, P. R., J. Sandoval-Castillo, E. van Sebille, J. Waters, and L. B. Beheregaray (2016), Oceanography promotes self-recruitment in a planktonic larval disperser, Scientific Reports, 6, 34205, doi:10.1038/srep34205.

van Dongeren, A. R., R. J. Lowe, A. W. M. Pomeroy, D. M. Trang, J. A. Roelvink, G. Symonds, and R. Ranasinghe (2013), Numerical modeling of low-frequency wave dynamics over a fringing coral reef, Coastal Engineering, 73(0), 178-190, doi:10.1016/j.coastaleng.2012.11.004.

Vetter, O., J. M. Becker, M. A. Merrifield, A. C. Pequignet, J. Aucan, S. J. Boc, and C. E. 
852

853

854

855

856

857

858

859

860

861

862

863

864

865

866

867

868

869

870

871

Pollock (2010), Wave setup over a Pacific Island fringing reef, Journal of Geophysical Research: Oceans, 115(12), C12066,, doi:10.1029/2010JC006455.

Willmott, C. J., S. G. Ackleson, R. E. Davis, J. J. Feddema, K. M. Klink, D. R. Legates, J. O'Donnell, and C. M. Rowe (1985), Statistics for the Evaluation and Comparison of Models, Journal of Geophysical Research, 90(C5), 8995-9005, doi:10.1029/JC090iC05p08995.

Winter, G., A. R. van Dongeren, M. A. de Schipper, and J. S. M. van Thiel de Vries (2014), Rip currents under obliquely incident wind waves and tidal longshore currents, Coastal Engineering, 89, 106-119, doi:10.1016/j.coastaleng.2014.04.001.

Zaker, N. H., J. Imberger, and C. Pattiaratchi (2007), Dynamics of the Coastal Boundary Layer off Perth, Western Australia, Journal of Coastal Research, 23(5), 1112-1130, doi:10.2112/04-0374.1.

Zhang, Z., J. Falter, R. Lowe, and G. Ivey (2012), The combined influence of hydrodynamic forcing and calcification on the spatial distribution of alkalinity in a coral reef system, Journal of Geophysical Research: Oceans, 117(C4), doi:10.1029/2011jc007603.

Zhang, Z., J. Falter, R. Lowe, G. Ivey, and M. McCulloch (2013), Atmospheric forcing intensifies the effects of regional ocean warming on reef-scale temperature anomalies during a coral bleaching event, Journal of Geophysical Research: Oceans, 118(9), 4600-4616, doi:10.1002/jgrc.20338. 